\title{
The Effect of Coding on Students' Visual-spatial Reasoning Skills
}

\author{
Ramazan Atasoy and Celalettin Özden \\ Turkey Ministry of National Education
}

\section{Abstract}

This work aimed to examine the effects of coding utilization in the technology and design course on students' visual-spatial reasoning skills. The study is based on a sequential mixed-method design. The quantitative dimension of the research was conducted in a random experimental pattern, with the implemented pre-test and posttest in the control group; the qualitative dimension utilized the interview technique. The reserarch sample included students of Şehit Hüseyin Ruso Secondary School in Nicosia, Northern Cyprus, in school year 2016 -2017. Visual-Spatial Reasoning Test developed by the researcher was used for obtaining quantitative data, and a semistructured interview form for qualitative data. The quantitative data were analyzed with the use of the independent sampling t-test, Cohen's d effect size coefficiency, and two-way variance analyses; content analysis was implemented for qualitative data. It was established that spatial reasoning skills of the students who used coding are significantly different to those of students who did not use coding; experimental group had a positive attitude toward the course and used their cognitive, sensory and psychomotor skills on a high level. It can be said that coding is an important factor for developing visual-spatial reasoning skills of students in this context.

Keywords: coding; education; Scratch; skills; visual - spatial reasoning

\section{Introduction}

It is supposed that coding, which is very popular in information technologies in today's world, would be determinant in educating individuals who will be able to meet the increasing need of the software field in the future (Sayın \& Seferoğlu, 2016). Scientific and technical progress helps and gives new opportunities and occasions to teach and to improve learning environments (Rososzczuk, 2015). Designing learning experiences directed to coding from the preschool age and its implementation into the learning environment in developed educational systems is an indication of this issue's importance (Akpınar \& Altun, 2014). It has become a necessity for educational systems 
to transform themselves in this paradigm where the internet of objects is considered by economy-oriented trends like Industry 4.0 and Society 5.0 (Atasoy \& Güçlü, 2020). This conversion of skills expected from students in the $21^{\text {st }}$ century has the potential to influence their future professional orientation. It is considered an indicator of this change that the robots based on artificial intelligence are taking place in our daily lives of the humans who invented and control them (Henning, 2018). These rapid developments in the robotic field will make sense with software that will enable new mechanical and digital technologies to be used for the intended purpose. In order to meet the needs for software, coding education has begun to penetrate students' educational experiences from a young age. Code Org., Cod Club, CoderDojo, Scratch, Alice, etc. are the internet applications and coding education programs which provide free utilization (Demirer \& Sak, 2016). Coding is introduced as a school subject in the United States and most of European Countries, whereas other countries are carrying on with the work needed for the inclusion of coding into their curriculum (European Schoolnet, 2014). Since 2013, in many regions of South Korea, Britain, France and United States of America, the implementation of many interdisciplinary courses and educational classes directed to students and teachers has started (Demirer \& Sak, 2016).

Coding is substantial computer programming work. Computer programming is a process of transferring simple or complex data to computers with algorithms by using numbers 1 and 0 . Computer programming is a complicated process and requires learning abilities of the highest degree. In order to overcome this difficulty and bring programming education to people of relatively young age, coding education has entered the educational curriculum of the countries with Scratch and similar programs (Çağlltay \& Fal, 2015). The algorithmic content of coding education contributes to the development of students' computational thinking skills (Taylor et al., 2010). At the same time, coding also contributes to the development of reflective and creative thinking skills, problem-solving skills in technology-intensive environments, and natural language development (Flannery et al., 2013; Sanjanaashree et al., 2014). In addition, there are studies that show coding provides positive contributions to higher level cognitive skills such as analysis, synthesis, evaluation, the ability to apply and transfer knowledge to practice, and spatial thinking skills (Akpinar \& Altun, 2014; Demirer \& Sak, 2016; Miller et al., 1988). Whereby coding training students also have the opportunity to transfer their knowledge and skills from one area to another (Fee et al., 2017; Winter et al., 2018).

Digital literacy skills are of the most important required of students in the $21^{\text {st }}$ century, after the basic processing skills (Popat \& Starkey, 2019; Wing, 2006). Coding and programming enables us to have a voice in global competition and produce valueadded products of high quality. Steve Jobs also recommends computer programming and code writing to everyone. According to this view, coding or programming will leave its mark on the $21^{\text {st }}$ century skills (Demir, 2017). Therefore, it is necessary to enhance digital learning environments, place coding into new educational approaches, 
position digital skills during the redesign of curricula, and make computer-supported education widespread in teaching coding (Kanaki \& Kalogiannakis, 2018).

It is noticeable that the use of coding has been introduced in different disciplines and in designing different educational environments. Coding that allows transfer of knowledge and interdisciplinary experiences has the potential for effecting spatial ability. Some of the researches on coding in literature are as follows: Friend et al. (2018) have researched learning math through coding and art; Erol and Aşkım Kurt (2017), and Tugun et al. (2017) have researched the effect of Scratch on the motivation of students; Kalelioğlu (2015) has examined the effect of coding on problem-solving skills; Calder and Taylor (2010) have explored the interaction of using Scratch and mathematical skills; Fessakis et al. (2013) focused on preschool education students' competence for the development of higher-order thinking and algorithmic problemsolving skills with computer programming; Taylor et al. (2010) have examined the influence of coding on shaping the future of mathematics; Choi et al. (2013) established that coding based technology supported mathematics teaching; Calao et al. (2015) have analyzed the influence of coding with Scratch on mathematical thinking skills; Saltan and Kara (2016) performed a study on whether or not teachers of computer technology considered Scratch as the software which provides algorithmic visualization; Yükseltürk and Altık (2016) researched attitudes related to programming and coding; Serpe (2017) has researched the effect of teaching mathematics with the use of games in coding. These studies witness the prominence of research into the digital literacy field with the intense and prominent use of visual-spatial skills.

Recent researches showed that visual - spatial reasoning skills are a core competency which plays an important role across a large number of disciplines, particularly math and sciences (Winter et al., 2018). Visual - spatial quantity can be defined as a cognitive characteristic that gives a measure of the ability to conceptualize the spatial relations between objects (Clement \& Battista, 1992; Halpern, 2000). Visual - spatial intelligence is a kind of ability used in many fields such as navigation in the real world, finding direction in daily life, designing of indoor and outdoor environments, repairing and sportive activities (Cox et al., 2005; Jones \& Burnett, 2008; Yüksel, 2013). The basis of visual-spatial ability is to perceive the visual world correctly. Students with developed visual-spatial skills are able to shape perceptions in their minds, transform these perceptions creatively, and produce visual experience without a physical stimulant. However, it should not be overlooked that all other abilities revealed by Gardner (2004) in the theory of multiple intelligences have the potential to affect each other. Spatial abilities include the ability to visualize objects in space, to define them from different angles, or to move all their parts separately. Spatial ability is defined as the ability to change and use objects and parts in two and three-dimensional spaces (Kabakçı \& Demirkapı, 2016). Two sub-dimensions of spatial ability, including spatial relations and spatial visualization, are mentioned (Olkun \& Altun, 2003). Spatial relations pertain to deciding which of the group objects on paper is rotated. Spatial visualisation involves 
mental actions such as converting from two dimensions to three-dimensional through mental folding or integration. Although different concepts such as spatial visualization, visual-spatial ability, spatial comprehension, three-dimensional visualization and spatial thinking are used instead of spatial ability, almost all of them refer to same or similar meanings (Mumcu \& Yildız, 2015). Visual - spatial thinking is about the individual's ability to make mental transformations and syntheses of objects' images.

Studies on spatial ability in literature have not been clearly outlined in terms of concept and expression. Hovewer, it can be said in general terms that spatial thinking has a close relationship with mathematical thinking (Olkun \& Altun, 2003). This claim can be detected in many works (Günay, 2015; Kalay, 2015; Özlü, 2014; Turgut, 2007; Yolcu, 2008). Although there are many studies on visual-spatial intelligence in literature, most of them are related to mathematics and geometry courses through play (Heng et al., 2014). Hegarty and Kozhevnikov (1999) researched the types of spatial representations and mathematical problem solving; Winter et al. (2018) explored mathematical analysis, coding and spatial reasoning; Demirkaya and Masal (2017) researched the relationship between geometrical games and spatial ability. Results of research by Friend et al. (2018) showed that student learning and abilities of visual-spatial thinking and coordinate graphing have a significant correlation to using LEGO blocks. Gül and Karataş (2015) researched the relationship between achievements in transformation geometry and spatial ability. Webb (1984) also found a relationship between spatial ability and various programming components in a short course in Logo programming. Çaliskan and Elliot (2016) have researched the dynamic geometrical software and its influence on spatial thinking skills of students; Rososzczuk (2015), Kalay (2015) and Topaloglu (2011) have examined the effect of the educational environment formed by Cabri 3D on spatial direction; Batdal Karaduman and Kök (2012) have researched the effect of the educational program for gifted children on spatial abilities. Hartatiana et al. (2018) researched the effect of learning activities with Cabri 3D on the spatial reasoning skills in mathematics class. They recommended using Cabri 3D program in their class to mathematics teachers in the conclusion of the research. Jakoš and Verber (2016) conducted a research on learning programming skills with educational games with sixth-grade students. According to the research conducted by Gold et al. (2018) on developing the spatial abilities of Geology department students, games or video games based on construction contribute to developing spatial abilities, both in school educational programs and out of school education during childhood and adolescence.

With regard to the development of visual-spatial reasoning skills, coding can be integrated at several points. The competencies of students to use their visual-spatial skills are extremely important in examining the content of technology and design courses. In this context, visual-spatial skills are indispensable in designing a technological product. Many educational practices in schools today lack visual-spatial reasoning skills outputs, and this means many spatially talented students are not being identified, encouraged or developed. Neglecting visual-spatial talented students causes economic and societal 
implications such as lost promising innovators and innovations (Wai \& Kell, 2017). It is thought that designing a product with visual-spatial skills and ICT skills can affect student learning. In addition, a computer-assisted learning environment that supports curiosity, interest and motivation in learning can be a useful tool in developing visualspatial reasoning skills. As a matter of fact, the results of the analysis of students' educational needs in the technology and design course conducted by the researcher revealed they were mainly aimed at learning through coding.

Maviş (2010) has stated that technology and design courses are carried out with supporting information technologies in the USA and EU Countries. In this respect, other countries can utilize information technologies for learning experiences. Therefore, the technology and design courses in Northern Cyprus performed with an understanding based on labor-intensive hand workmanship are not sufficient for reaching the actual student mastery of technology and design field, nor for developing their visual-spatial abilities. Therefore, there are no adequate projects or program developing studies based on coding or technology education in Northern Cyprus, as opposed to the rest of the world (Özden \& Atasoy, 2019). This research is an example which manifests that technology and design courses could be integrated with software teaching, in order to meet the needs of these areas. In this context, it is presumed that this study can contribute to reserach for developing coding and technology education programs. There are many researches about spatial ability and mathematics, but few on the correlation between spatial ability and technology and design course. Hereby, this paper somewhat bridges the existing gap by presenting an interdisciplinary research on the relationship between coding, spatial ability and technology design courses.

This study reveals the effects of coding on visual-spatial reasoning skills, which come to the forefront besides other skills in technology and design courses. There are no existing studies for developing programmes for learning experiences with coding in Northern Cyprus. In this respect, we stress the importance of coding effects on student learning and its implications for developing future inclusive learning models, i.e. introducing coding into the curriculum. We consider that in this digital world where everything is done on the Internet and by computers, integration of coding with technology and design courses would be more effective for learning of the Generation Z, i.e. computer children.

\section{The aim of the research}

In this research we aimed to reveal the effect of coding on visual-spatial reasoning skills of students. Therefore, answers to the following questions were examined in order to reach the subgoals of the research.

i. Is there a significant difference between the pre-test scores of the visual-spatial reasoning in the experimental and control groups?

ii. Is there a significant difference between pre-test, post-test and permanency test scores of experimental and control groups? 
iii. What is the opinion of the students who take coding training on the effectiveness of technology and design course?

\section{Limitations}

i. This research was applied on the seventh-grade students of Şehit Hüseyin Ruso Secondary School in Northern Cyprus in school year 2016 - 2017.

ii. Personal computer and interactive smart board were used in teaching activities in this experimental research.

\section{Method}

\section{Research design}

This study is designed as a mixed model where both quantitative and qualitative methods are used together. It was conducted as a sequential descriptive pattern (Creswell, 2014). Therefore, the effect of the implemented coding training in the experimental group, and the effect of the traditional method implemented in the control group, on students' spatial reasoning skills were analyzed primarily by obtaining quantitative data, and then by obtaining qualitative data. Pre-test and post-test experimental pattern in the control group was applied in the quantitative dimension of the research. While technology and course design revised with coding was applied to the experimental group, traditional technology and course design was applied to the control group. Both groups were trained by the researcher. However, the support from an ICT teacher during teaching of the experimental group was provided. The research lasted for 8 weeks. The classroom environment was equipped with an interactive smart board, and all external disturbant factors were minimized as much as possible.

\section{Research sample}

The research included seventh-grade students from Şehit Hüseyin Ruso Secondary School from the city center of Nicosia, in school year 2016/2017. The study was carried out with the seventh-grade students who had low education anxiety and had adapted to their secondary school life. All the students participated in the research voluntarily. Special attention was paid to forming the study groups so they would be in the same class level (7th grade), and for the class to have similar academic performance. Information about socio-economical levels and academic achievement of the $7^{\text {th }}$-grade classes was obtained from the administration of the school. Students of equal academic achievement level who would be in the experimental and control group were chosen from the $7^{\text {th }}$ classes by random method. Great majority of students participating in the research had a personal computer and the Internet in their home. The students' families were of middle income (higher than minimum wage) or of lower income (working with minimum wage). Students who had extremely high or low academic achievement were excluded. There were 30 students in each group. The results of the t-test analysis for determining the equivalence of the experimental and control group 
showed no statistically significant difference between visual-spatial reasoning skills of the students in these groups. This result indicates that the groups can be accepted as equivalent in the results of the pre-test of visual-spatial reasoning skills.

\section{Data collection tools}

Visual-spatial reasoning pre-test, post-test, and permanency test developed by the researcher were applied for quantitative data collection during the research, and the SPSS 23 programme was used for data analysis. Necessary official permissions for conducting the research were obtained from the Ministry of National Education. A question bank was composed of 62 questions for visual-spatial reasoning test. The questions were examined by four specialists in this field and by three linguists. 50 questions were drawn from the question pool according to the specialists' opinions. 15 days later the specialists evaluated the items again and the spatial reasoning test was formed by the researches. In this way, content validity of the research was obtained.

This Visual - Spatial Reasoning Measure Test consisted of three parts. The first part comprised 13 questions titled Mental Rotation, the second part consisted of 12 questions titled Spatial Distinctiveness and Analyzing, and the third part consisted of 25 questions named Depth Perception and Mental Completion. The test entailed multiple choice questions, "A-B-C-D”. One minute was given for each question in the test. To obtain the data, the researchers performed the test separately in every region. The test was preapplied on $1637^{\text {th }}$-grade students in public secondary schools of the Turkish Republic of Northern Cyprus as follows: in Nicosia on 56 students, in Famagusta on 38 students, in Kyrenia on 37 students, in Iskele on 17 and in Güzelyurt on 15 students.

Calculations for the difficulty and distinctiveness of the items are conducted for achievement and ablity tests which measure knowledge and skills. It is expected that the difficulty value of the item "p" should be around 0.50 . If this value increases to +1 , the difficulty level of the item decreases; if the value decreases to 0 , the difficulty level of the item increases (Büyüköztürk et al., 2016). The distinctiveness of the item reveals the level which differentiates the individuals according to the measured quality. It ranges between +1 and -1 . If the value of the item's distinctiveness decreases to negative values, it reveals the reverse measurement of the item, which then needs to be excluded from the test (Büyüköztürk et al., 2016). If the indexes for distinctiveness are $>0.40$, the item is very good; if they are between $0.39-0.30$, the item is good; if they are between $0.20-0.29$, they need to be developed; if the index is $>0.20$, the item should be removed from the test (Büyüköztürk et al., 2016). 21 items are defined as easy, 20 as intermediately difficult, 9 of them are defined as difficult. With regards to the distinctiveness indexes of the items, 17 were defined as good and 33 as very good. The average difficulty of the test is calculated as 0.55 .

For obtaining the qualitative data, this study used the Interview Form Related with Technology Design Course Revised with Coding. The form consists of the questions about the opinion of students who use coding on the effectiveness of the technology 
and design course. During the preparation of the qualitative questions, primarily the purpose of the research was taken into consideration. The opinions of the four specialists in the field were also considered, and a literature survey on the subject was conducted. According to the related literature review and the experts' opinions, a pool of possible questions was extracted and the semi-structured Interview Form was designed. The Form was presented to six experts. Experts' opinions were evaluated via an evaluation form created by the researcher. As a result of the evaluations of the experts, the interview form was finalized and it consisted of four questions. Upon this process, according to the experts' opinions, a pilot interview was conducted by the researchers to validate the clarity of the questions and to make the necessary corrections. The interview form was finalized by getting feedback from the experts and from the pilot study.

The interviews were conducted in May 2017. The reliability of the content analysis for the qualitative data in the study was ensured by two specialists separately, for the processes of coding, categorization and thematisation. The reliability of the codes and themes have been checked by two coders; the compatibility between the coders was cross-checked in order to ensure that all codes, themes, and contents are corrected. At the end of the coding process, the researchers reviewed all the codes and themes. Interview Form Related with Technology Design Course Revised with Coding was applied face-to-face and the questions from the interview, which lasted approximately 30-35 minutes, were put to all the participants in the same order. The interview data was recorded with an audio device.

Themes and codes obtained from qualitative data were subjected to content analysis by NVivo 12 package program. Participants were coded as $\mathrm{K}_{1}, \mathrm{~K}_{2}(\ldots)$ and the data arranged and interpreted by the researcher with regard to the themes and subthemes. Some students' opinions were quoted directly to reflect their views (Yıldırım \& Şimşek, 2011) and to keep the identity of the participants confidential.

The analysis and interpretation of all the data by researchers finding common themes and codes ensured the reliability of the study. First, both researchers coded the data separately and, after that, the percentages of correspondence between the encodings were calculated at $82 \%$. According to Şencan (2005), and Yildırım and Şimşek (2011), this percentage of compliance is considered sufficient for reliability. Over $70 \%$ of this similarity reflects the reliability of the study. Disagreements were discussed and necessary adjustments were made.

Permanency tests were applied six weeks after the research was completed. In experimental researches, a follow-up study (permanency test) is recommended after a certain period of time (Heppner et al., 1999). Although the permanency test time varies according to the aims and characteristics of the study, literature states that it is sufficient to apply it six weeks after the end of the study (Campell \& Stanley, 1963; Brown et al., 2008). Scratch program for coding was also used in the implementation 
part. This program was preferred in the research because it is free, of open access, in Turkish language, and useful for many different disciplines.

\section{Research steps}

\section{Integrating coding into technology and design teaching program}

1 Survey about the needs with regard to the technology and design course was conducted amongst students who were studying in state schools throughout Northern Cyprus and were selected by stratified sampling.

2 The target achievements of the program were determined according to the items that emerged in the needs analysis, and these target gains were classified according to the cognitive domain level.

3 Course plans and activities for technology and design that contain coding directed to targeted gains were prepared with the experts (ICT and technology and design teachers).

4 The program designed according to the ASSURE teaching model and prepared for the experimental group was taught with the use of the student-oriented approach. In the design phase, the students and their educational needs were analyzed, individual characteristics and readiness levels were determined. Accordingly, we determined the aims in compliance with the educational needs of the learners analyzed in the first step. For example: Explaining the importance of the line element in a design; Giving examples of computer use in the field of technology and design; Writing algorithms by using a line and turning two-dimensional shapes into three-dimensional shapes.

Appropriate teaching techniques and materials were chosen in the stage of strategies, technologies, media and materials selection. Papers, pencil, smart board and laptop were used as educational tools. In the step of utilizing technology, media and materials, the environment was arranged for the use of appropriate materials by the students in the classroom. Subject slides were prepared. Learners were informed about the objectives, the learning content and the benefits of this learning process.

During the required student participation phase, activity plans and project examples were prepared for the students. It was determined beforehand how the students would participate in individual and group activities. This enabled each student to participate effectively. During the evaluation and revision phase, students were asked to assess themselves. In addition, the students also evaluated the benefits of the course by evaluating the activities in the course. The level of reaching the aims is determined according to the projects produced and the processes gone through in the course. Some example tasks were: write a simple algorithm, draw an object from different points of view with coding, use logical variables.

5 There was no intervention in the control group where the traditional teaching program was applied. For all students, visual-spatial reasoning test was applied as the pre-test, post-test and permanency test. 


\section{The experimental study process (The program's application and procedural steps)}

$1^{\text {st }}$ Week: Implementing visual-spatial reasoning pre-tests, with emphasis on innovation, design, the designing process and the line's importance in it.

$2^{\text {nd }}$ Week: The students write simple algorithms using the paper-pencil method and describe the sequence of algorithms; the sequence of operations in an algorithm was explained to the students. The students apply examples from the menu of motion, control and pen by running Scratch program. The students apply location and direction commands in order to change the position of the character.

$3^{\text {rd }}$ Week: Students do exercises in using lines that transform two-dimensional shapes into three-dimensional shapes. They develop three-dimensional shapes and various architectural designs in the computer environment with Scratch program. The students perceive the relation with geometry courses at this point. They change the appearance of the character, reverse the character and use "if-else" commands with Scratch program.

$4^{\text {th }}$ Week: Students perceive the appearance of objects from different angles; they rotate the characters in certain degrees and apply back and forward motions. The object at this point was enabling the students to produce ideas on moving mechanical designs, and relating these activities with mathematics and other courses. The students used random value assignment and logical-mathematical operations.

$5^{\text {th }}$ Week: The students choose stages properly with relation to characters and draw the images according to their appearance from different angles. The idea of this stage was to provide students with the opportunities to produce various designs and for them to associate these activities with mathematics and other courses. Conditions, defining data and assigning variables were all implemented.

$6^{\text {th }}$ Week: The students create new characters and design elements in Scratch; they create animations with the designed characters. The idea behind this stage was to produce and present new ideas for facilitating the life of disabled people or the elderly, and associate these activities with geometry, art and science courses. Experimental group students performed projects using logical variables, reversing characters, "if - else" commands, random value assignment, variable assignment and direction commands with Scratch program.

$7^{\text {th }}$ Week: The students design characters with regard to changing far and near appearance of an object. They place these characters in different positions and facilitate movement by effects. The goal was to create the advertisement for the developed product and connect these activities with geometry, mathematics, art and science courses. Students also evaluate the projects.

$8^{\text {th }}$ Week: The students design products proper to their own desire and needs, and prepare these products as animation in the Scratch program. The students mutually evaluate their original products. 


\section{Statistical analysis}

Data obtained from the pre-test, post-test and permanency test have shown normal distribution according to Tabachnick and Fidell (2013). Therefore, it would be proper to perform the analysis with parametric tests. The T-test and two-way variance analysis for complex measurements were performed in the analysis of quantitative data. $\mathrm{p}<0.05$ value was considered as a statistically significant value. Qualitative data were subjected to content analysis, and themes and codes were determined. In order to use parametric tests in the research, it was also analyzed whether the research data meet the assumptions of normality, missing values (-), extreme values (-), multicollinearity and variance homogeneity. When the results of linear regression analysis of the visualspatial reasoning test were examined, the VIF values were in range between 1.00 and 1.025, the CI values were between 1 and 9.159, and the tolerance values were quite high, in range between 1.00 and .976 . Also, It was observed that multicollinearity correlation assumptions were met.

\section{Research results}

Quantitative statistics and qualitative interviews were conducted in the research to determine the efficiency level of the applied program of technology and design course revised with coding on visual-spatial reasoning skills of students.

\section{Research question 1}

In the first subproblem of the study, we examined whether there was a significant difference between the pre-test scores in visual-spatial reasoning between the experimental and control groups. Firstly, the distribution's normality was tested with the Kolmogorov-Smirnov test. Shapiro-Wilk is recommended in cases where the number of observations is less than 30, and Kolmogorov-Smirnov in cases where it is 30 or more (Can, 2014).

Table 1

Kolmogorov-Smirnov Normality Test result of the pre-, post- and permanency measurements of the experimental and control group

\begin{tabular}{llccc}
\hline Groups & Measurement & Kolmogorov-Smirnov & $\mathrm{df}$ & $\mathrm{p}$ \\
\hline \multirow{3}{*}{ Experimental } & Pre-Test & .096 & 30 & .200 \\
& Post-Test & .094 & 30 & .200 \\
& Permanency & .119 & 30 & .200 \\
& Pre-Test & .145 & 30 & .107 \\
Control & Post-Test & .137 & 30 & .159 \\
& Permanency & .084 & 30 & .200
\end{tabular}

As it can be seen in Table 1, there are no statistically significant differences between the distributions of the observed measurements. All measurements, both in the experimental and control group, are normally distributed ( $p>.05)$. The data's normal distribution 
for both groups was also evaluated by the skewness [pre-test (E/C): .654/.792; posttest (E/C): .131/.419; permanency test (E/C): .247/.444] and kurtosis [pre-test (E/C): .049/.592; post-test (E/C): -.389/-.282; permanency test (E/C): -1.02/-.105], histograms, scattering diagram matrices (distributions were scattered close to the ellipse) and Q-Q graph distributions. The skewness and kurtosis values range between +1.5 and -1.5. It is recommended that all methods mentioned above be evaluated together, with the assumption of normal distribution (McKillup, 2012; Stevens, 2009; Tabachnick \& Fidel, 2013). According to this recommendation, we concluded that the distribution of normality and the variation coefficients of the data were in acceptable range.

In order to use parametric tests, homogeneity of variance should be examined (Büyüköztürk et al., 2016). Levene Test (see Table 4) was used to examine the variance homogeneity of the scores obtained from the pre-test, post-test and permanency tests of the experimental and control groups. The assumption of homogeneity of variances was confirmed and so the utilization of parametric tests validated.

The t-test for independent samples was implemented and the results are presented in Table 2.

Table 2

Results of the t- test for independent samples in experimental and control groups

\begin{tabular}{lccccccc}
\hline Groups & Tests & $\mathrm{N}$ & $\bar{\chi}$ & $\mathrm{Sd}$ & $\mathrm{Df}$ & $\mathrm{t}$ & $\mathrm{p}$ \\
\hline Experimental & pre-test & 30 & 20.03 & 6.5 & 58 & \multirow{2}{*}{427} & .67 \\
Control & pre-test & 30 & 20.76 & 6.7 & 58 & & \\
\hline
\end{tabular}

As it can be seen in Table 2, there is no significant difference between the experimental $(\bar{\chi}=20.03)$ and control group $(\bar{\chi}=20.76)$ in the visual-spatial reasoning pre-tests $\left(\mathrm{t}_{(58)=}=427, \mathrm{p}>.05\right)$. In this regard, it can be said that students from the experimental and control group were at an equal level in term of visual-spatial reasoning skills. According to Table 2, it can be concluded that both experimental and control group had equal visual-spatial reasoning test scores, so the first research question is answered.

In order to apply variance analysis to repeated measures, it is necessary to examine whether the assumption of sphericity is met. For this reason, Sphericity test was applied (Gamst et al., 2008). In cases where the sphericity assumption could not be met, variance analysis results were obtained by using Greenhouse-Geisser correction (Tabachnick \& Fidell, 2013).

Table 3

Mauchly's Test of Sphericity for experimental and control group's visual spatial reasoning tests scores

\begin{tabular}{ccccccccc}
\hline & & & & \multicolumn{3}{c}{ Epsilon } \\
\cline { 5 - 8 } $\begin{array}{c}\text { Within-Subjects } \\
\text { Effect }\end{array}$ & $\begin{array}{c}\text { Mauchly's } \\
\text { W }\end{array}$ & $\begin{array}{c}\text { Approx. } \\
\text { Chi-Square }\end{array}$ & sd & p & $\begin{array}{c}\text { Greenhouse- } \\
\text { Geisser }\end{array}$ & $\begin{array}{c}\text { Huynh- } \\
\text { Feldt }\end{array}$ & $\begin{array}{c}\text { Lower- } \\
\text { bound }\end{array}$ \\
\hline Measurements & .858 & 8.724 & 2 & .013 & .876 & .916 & .500 \\
\hline
\end{tabular}

When the results obtained from the repeated measurements of the visual-spatial reasoning test are examined, it is seen that the assumption of sphericity cannot be 
confirmed ( $\mathrm{W}=.858, \mathrm{p}<.05)$. Accordingly, Greenhouse-Geisser correction was used in examining the within-group effect regarding the measurements, and the results are presented in Table 3.

In order to use parametric tests, homogeneity of variance should be examined (Büyüköztürk et al., 2016). Levene Test was used to examine the variance homogeneity of the scores obtained from the pre-test, post-test and permanency tests of the experimental and control groups. Levene Test results are shown in Table 4.

Table 4

Results of the Homogeneity of Variance (Levene) Test applied to the scores achieved in the pre-, post-and permanency tests of the experimental and control groups

\begin{tabular}{lccccc}
\hline & $\mathrm{N}^{*}$ & $\mathrm{~F}$ & $\mathrm{df1}$ & $\mathrm{df2}$ & $\mathrm{p}$ \\
\hline Pre-test & 60 & .000 & 1 & 58 & .988 \\
Post-test & 60 & .000 & 1 & 58 & .96 \\
Permanency test & 60 & .128 & 1 & 58 & .722 \\
\hline
\end{tabular}

* Total number of the students

As shown in Table 4, it was found that there was no significant difference between the variances in both groups before the experimental procedure. In other words, the variances of the experimental and control group are homogeneous for all dependent variables according to the pre-test measurements $(F=.000, p>.05)$. According to the data obtained from the post-test measurements, it is confirmed that homogeneity of variance is achieved $(\mathrm{F}=.00, \mathrm{p}>.05)$. According to the results of the permanency test measurement, it was also confirmed that the variances were homogeneous $(\mathrm{F}=.128, \mathrm{p}>.05)$.

Box's $M$ test was applied to test the equality of covariance matrices of dependent variables. The results are also presented in the table below.

Table 5

Box's M Test for equality of covariance matrices

\begin{tabular}{lcccc}
\hline Box's M & $F$ & $d f 1$ & $d f 2$ & $p$ \\
\hline 10.805 & 1.699 & 6 & 24373.132 & .117 \\
\hline
\end{tabular}

According to Table 5 (Box's $M=10.805$ ), it is concluded that the assumption of multiple normalities is met for visual-spatial reasoning skills. Considering all the evaluations made for the data, all the assumptions necessary for performing two-way analysis of variance for repeated measurements were met.

\section{Research question 2}

In the context of the second research question, it was compared whether there is a significant difference between the post-test and permanency test scores of the experimental and control group. Arithmetic mean and standard deviation values of the experimental and control group's visual-spatial reasoning test, pre-test, post-test and permanency test scores are presented in Table 6. 
Table 6

Arithmetic mean and standard deviation values of pre-, post-and permanency test scores

\begin{tabular}{lllcc}
\hline Groups & Test & N & $\bar{\chi}$ & Sd \\
\hline \multirow{4}{*}{ Experimental } & Pre-test & 30 & 20.03 & 6.55 \\
& Post-test & 30 & 26.90 & 7.79 \\
& Permanency & 30 & 29.63 & 8.67 \\
\multirow{5}{*}{ Control } & Pre-test & 30 & 20.76 & 6.75 \\
& Post-test & 30 & 22.40 & 7.98 \\
& Permanency & 30 & 21.60 & 8.87 \\
\hline
\end{tabular}

According to the visual-spatial reasoning test results of the experimental group, the arithmetic mean of the pre-test scores was calculated as $\bar{\chi}=20.03$, the arithmetic mean of the post-test score was $\bar{\chi}=26.90$, and the arithmetic mean of the permanency test score was $\bar{\chi}=29.63$. The arithmetic mean of the pre-test scores of the control group was calculated as $\bar{\chi}=20.76$, the arithmetic mean of the post-test score was $\bar{\chi}=22.40$, and the arithmetic mean of the permanency test scores was calculated as $\bar{\chi}=21.60$.

In the light of these findings, the two-factor analysis of variance was applied to repeated measurements in order to determine whether there was any change when compared with the pre-test mean scores, post-test and permanency test mean scores of the experimental and control group. The results are presented in Table 7.

Table 7

Results of two-factor variance analysis of visual-spatial reasoning pre-test, post-test and permanency test scores of experimental and control groups

\begin{tabular}{lcccccc}
\hline Source & $\begin{array}{c}\text { Sum of } \\
\text { Squares }\end{array}$ & Df & $\begin{array}{c}\text { Mean } \\
\text { Square }\end{array}$ & $F$ & P & $\mathrm{n}^{2}$ \\
\hline Between-Subjects & 8583.11 & 59 & & & & \\
Group (E/C) & 696.20 & 1 & 696.20 & 5.12 & .027 & 0.67 \\
Error & 7886.91 & 58 & 135.98 & & & \\
Within-Subjects & 4259.33 & 120 & & & & \\
Measurements(pre, post, permanency) & 924.21 & 2 & 462.10 & 19,482 & .000 & \\
Group*Measurement & 583.63 & 2 & 291.81 & 12.30 & .000 & \\
Error & 2751.48 & 116 & 23.72 & & & \\
Total & 12842.44 & & & & & \\
\hline
\end{tabular}

According to the variance analysis in Table 7, there is a significant difference between the total scores of the permanency test, post-test and pre-test scores of the experimental group and the control group. In other words, the group effect was found to be significant $\left[\mathrm{F}_{(1-58)}=5.12, \mathrm{p}<.05\right]$. Based on this finding, it can be said that there is a significant difference between the mean scores obtained from the visual-spatial reasoning scale, without any distinction between the pre-test, post-test and permanency tests of the experimental and control groups.

As observed in Table 7, it is seen that the difference between the mean scores of pre-test, post-test and permanency tests of all participants in the experimental and control group, without discrimination, is significant. $\left[\mathrm{F}_{(2-116)}=19.48, \mathrm{p}<.05\right]$. In this 
context, it can be said that the visual-spatial reasoning levels (skills) of the participants change depending on the experimental process when no group discrimination is made. In addition, the result of the joint effect, which is critical for this study (Group Measurement), was found to be significant $\left[\mathrm{F}_{(2-116)}=12.30, \mathrm{p}<.05\right]$.

According to the results obtained from the analysis of variance, the Bonferroni test, which is one of the post-hoc tests, was applied according to the pre-test, post-test and permanency test scores of all participants to determine a significant difference between the groups. The Bonferroni test shows the difference between the groups at a statistically significant level, free of I. type and II. type errors (Miller, 1969). The results are presented in Table 8.

Table 8

Bonferroni Test on the means of pre-, post- and permanency test scores of experimental and control groups

\begin{tabular}{|c|c|c|c|c|c|c|c|}
\hline & & \multicolumn{3}{|c|}{ Experimental } & \multicolumn{3}{|c|}{ Control } \\
\hline & & $\begin{array}{c}\text { Pre-test } \\
\mathrm{MD}^{*}\end{array}$ & $\begin{array}{l}\text { Post- test } \\
\text { MD }\end{array}$ & $\begin{array}{c}\text { Permanency } \\
\text { test } \\
\text { MD }\end{array}$ & $\begin{array}{l}\text { Pre-test } \\
\text { MD }\end{array}$ & $\begin{array}{l}\text { Post- test } \\
\text { MD }\end{array}$ & $\begin{array}{c}\text { Permanency } \\
\text { test } \\
\text { MD }\end{array}$ \\
\hline \multirow{3}{*}{ Experimental } & Pre-test & - & $-6.86^{*}$ & $-9.60^{*}$ & -.73 & -2.37 & -1.57 \\
\hline & Post-test & $6.86^{*}$ & - & -2.73 & $6.13^{*}$ & 4.50 & 5.30 \\
\hline & Permanency & $9.60^{*}$ & 2.73 & - & $8.87^{*}$ & $7.23^{*}$ & $8.03^{*}$ \\
\hline \multirow{3}{*}{ Control } & Pre-test & .73 & $-6.13^{*}$ & $-8.867^{*}$ & - & -1.633 & -.83 \\
\hline & Post-test & 2.37 & -4.50 & $-7.23^{*}$ & 1.63 & - & .80 \\
\hline & Permanency & 1.57 & -5.30 & $-8.03^{*}$ & .83 & -.80 & - \\
\hline
\end{tabular}

${ }^{*} \mathrm{MD}$ : Mean difference. The mean difference is significant at the .05 level.

According to the Bonferroni comparison test in Table 8, the difference between the mean of visual-spatial reasoning pre-test $(\bar{\chi}=20.03)$ and post-test $(\bar{\chi}=26.90)$ applied to the experimental group is significant $\left(-6.867^{*}, \mathrm{p}<.05\right)$. Similarly, the difference between the pre-test mean $(\bar{\chi}=20.03)$ and the permanency test mean $(\bar{\chi}=29.63)$ of the experimental group was found to be significant $\left(-9.600^{*}, \mathrm{p}<.05\right)$. There was no significant difference between the mean of the post-test $(\bar{\chi}=26.90)$ and the permanency test $(\bar{\chi}=29.63)$ of the experimental group $(2.73, \mathrm{p}>.05)$.

The differences between the mean of visual-spatial reasoning pre-test $(\bar{\chi}=20.76)$ and post-test $(\bar{\chi}=22.40)$ applied to the control group is not significant $(-1.633, \mathrm{p}>.05)$. Similarly, the difference between the pre-test mean $(\bar{x}=20.76)$ and the permanency test mean $(\bar{\chi}=21.60)$ of the control group was found not to be significant $(-.83, \mathrm{p}>.05)$. There was no significant difference between the mean of the post-test $(\bar{\chi}=22.40)$ and the permanency test $(\bar{\chi}=21.60)$ of the control group $(.800, \mathrm{p}>.05)$.

The graphic result of the pre-test, post-test and permanency test which were applied to the experimental (group 1) and control (group 2) group are shown in Figure 1 in an integrated form. It is seen that the experimental group and control group are equal in the pre-test results (measurement 1 ), which means they were equal at the beginning of the research. The difference between the post-tests of the groups (measurement 
2) shows a significant increase in favor of the experimental group. The difference between permanency tests of the experimental group and control group is high, as can be seen in the chart (measurement 3). For the differences between the post-test and permanency test in favor of the experimental group, it can be said that the program of the technology and design course revised with coding has a significant effect on visual-spatial reasoning skills of the students.

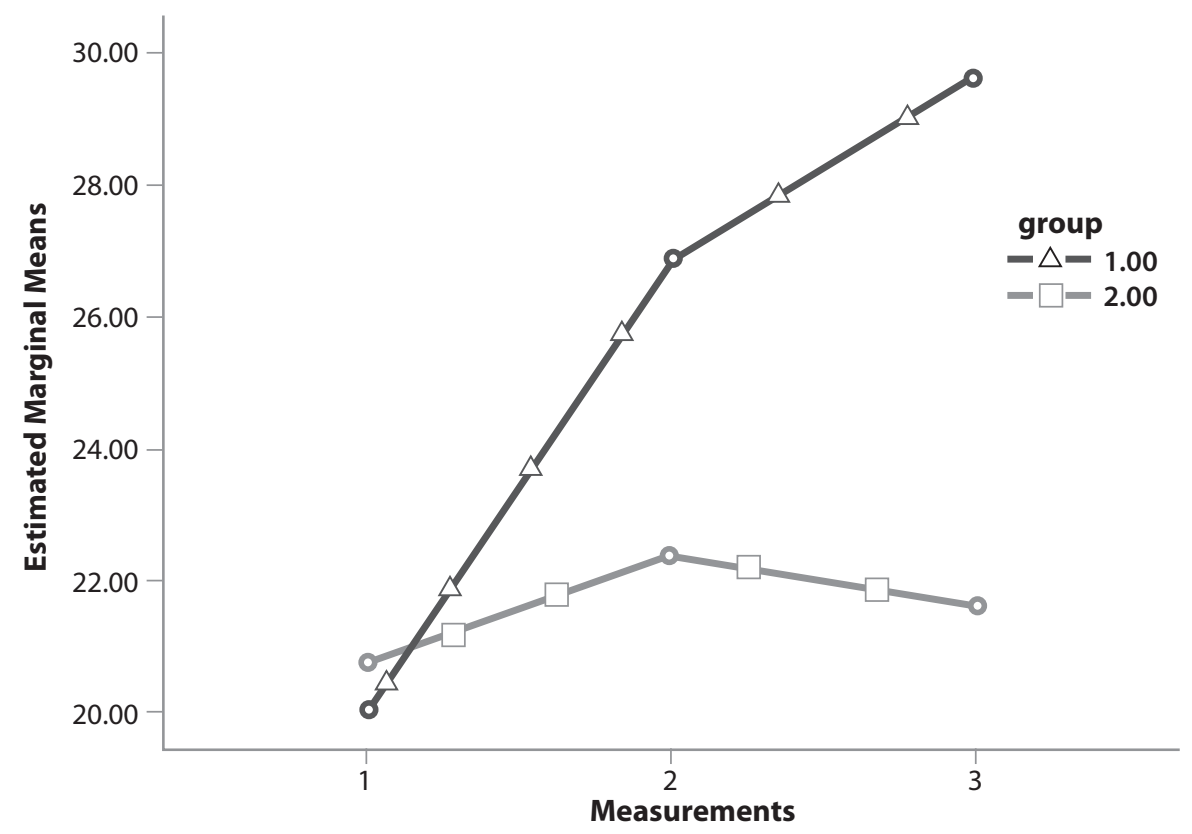

Figure 2. Two - way variance graphic for complex measurement

\section{Research question 3}

The opinions of the students who have undergone coding teaching about the effectiveness of the technology and design course were placed in the qualitative dimension of the research. The main themes - cognitive, affective, skills, and external - and the related subthemes were coded.

According to Figure 3, it is visible that the students evaluated the effectiveness of the course with regards to four main themes. It is considered that the opinions of the students related to cognitive outcomes were concentrated on implementing, reasoning, evaluation, analysis and permanency. As these subthemes are known as high-level cognitive outcomes, we can infer there are positive effects of the learning process on visual-spatial skills. In addition to this, it is manifest that relatively high-level cognitive processes of knowledge and perception have a positive reflection on the permanency of learning. The opinions of students who undergone coding teaching related to cognitive outcomes are as follows: 


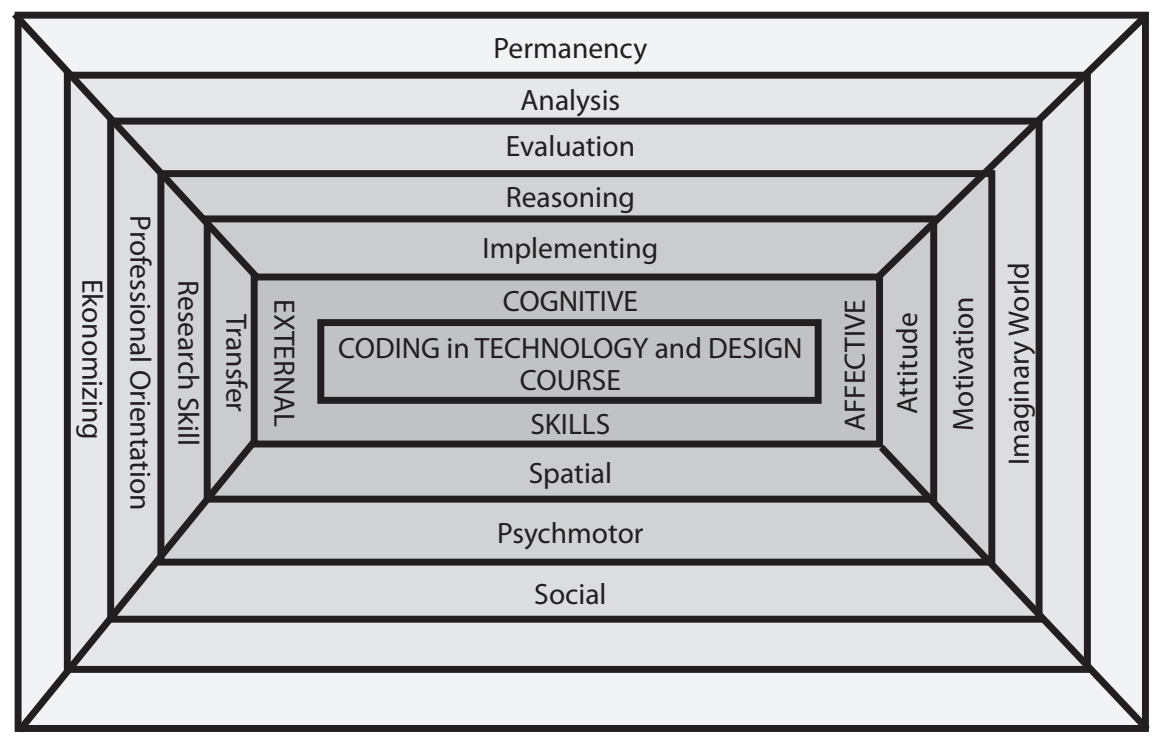

Figure 3. Model for using spatial skills

I can find a solution to any problem after coding. If something is broken, we can use reasoning to repair it $\left[\mathrm{K}_{11}\right]$. It has a positive effect on my design; we were able to draw three-dimensional shapes $\left[\mathrm{K}_{17}\right]$. Courses were conducted practically. Something remains in our mind $\left[\mathrm{K}_{23}\right]$. I can design new products. I could remember the issues which were learned in the former courses $\left[\mathrm{K}_{6}\right]$. I couldn't understand what they were drawing before the practice. They were drawing some strange things and I couldn't understand what they were. However, after I started this program, everything changed $\left[\mathrm{K}_{5}\right]$. I have started to perceive everything $\left[\mathrm{K}_{18}\right]$. I can understand the sizes of an object when I look at it. Even I can make simple architectural drawings $\left[\mathrm{K}_{3}\right]$. I can easily understand mathematical problems $\left[\mathrm{K}_{16}\right]$. I used to have difficulties in the mathematics course, but after learning Scratch everything seems easier $\left[\mathrm{K}_{21}\right]$. Coding has a positive effect on geometry in the mathematics course, on volcanos and molecules in the science course, on drawing maps at social sciences course $\left[\mathrm{K}_{18}\right]$.

There are 3 subthemes placed in the affective outcomes of the students who had coding practice: attitude, motivation and imaginary world. It can be said that students who had coding training exhibit positive attitudes about imagining, designing visualspatial factors, and towards using objects containing visual-spatial aspects. It is stated that the technology and design course that incorporated coding made easier to perceive and materialize the objects with visual-spatial dimensions. The research has revealed that Scratch program is efficient for imaginging and improving new ideas. According to the opinions of the students, it is also understood that courses that entail coding reflected positively on permanency and comprehensibility of the cognitive outcomes, and motivated the students. It was observed that the learning process has become a playful and funny process due to coding. Moreover, there are significant changes in 
the students' attitudes. The opinions of the students who have had coding training about the affective outcomes are as follows:

While we were using coding in design teaching, creative and new ideas emerged $\left[\mathrm{K}_{13}\right]$. Scratch program has provided an increase in my imagination $\left[\mathrm{K}_{4}\right]$. The activity which I liked most in the course was to create the characters and stretch my imagination $\left[\mathrm{K}_{27}\right]$.3-D drawing expands our imagination $\left[\mathrm{K}_{25}\right]$. In mathematics, we can distinguish the length-depth of shapes $\left[\mathrm{K}_{1}\right]$. All of these codings and projects made me feel warm to the course $\left[\mathrm{K}_{11}\right]$. Coding is necessary $\left[\mathrm{K}_{16}\right]$. Coding training was pleasurable $\left[\mathrm{K}_{28}\right]$. Coding training is required $\left[\mathrm{K}_{1}\right]$. I would have felt incomplete if $\mathrm{I}$ had not been trained in coding $\left[\mathrm{K}_{10}\right]$. The characters were so sweet, we moved them as we wanted $\left[\mathrm{K}_{9}\right]$. We cast the characters and it was fun $\left[\mathrm{K}_{19}\right]$. We had so much fun $\left[\mathrm{K}_{16}\right]$. Our imagination developed $\left[\mathrm{K}_{11}\right]$. Creative thinking develops our imagination $\left[\mathrm{K}_{23}\right]$. In other lessons we usually stay within the boundaries because they have rules $\left[\mathrm{K}_{27}\right]$.

There are 3 sub-themes placed in the main theme Skills: spatial, psychomotor and social skills. Besides the positive effects on cognitive and affective abilities of the students, use of coding entails positive effects on the students' skills to distinguish, shape and assemble visual-spatial objects. Opinions of students accentuate three dimensioned thinking, perceiving the object with all its dimensions and drawing in a digital environment, producing original designs, transferring the improved spatial skills to mathematics, art and other courses. Students stated that their spatial skills were increased and expressed the importance of coding practices, thinking, logical reasoning and being motivated. Students stated that working with computers and coding have an especially positive contribution to improving the planning of designs, developing projects and teamwork skills. The opinions of the students who have had coding training related to the skills outcomes are as stated below:

I have learned to draw three-dimensional drawings. I prefer three-dimensional visions while designing. We only see the front part of an object in a two-dimensional shape $\left[\mathrm{K}_{17}\right]$. We can see the sides and the back of an object in three-dimensional images $\left[\mathrm{K}_{14}\right]$. It provides an enriched environment $\left[\mathrm{K}_{11}\right]$. I couldn't draw three-dimensional shapes before. Now, however, I can even draw a car, bus or unformed objects besides geometrical objects $\left[\mathrm{K}_{16}\right]$. What we have learned in this coding teaching course helped us in other courses $\left[\mathrm{K}_{28}\right]$. We can distinguish the depth, the length and the height of the forms in mathematics course. Together with our friends we can distinguish the character from the background. $\left[\mathrm{K}_{1}\right]$. I combined the lines for creating characters and scenes for designing. I prefer three-dimensional forms instead of two-dimensional ones and, therefore, three-dimensional forms present enriched imaginations $\left[\mathrm{K}_{23}\right]$. I loved three-dimensional patterns. I could not draw three-dimensional forms before the technology and design course. After I went through this course, I draw much better forms $\left[\mathrm{K}_{5}\right]$. I can transform a square, triangle, an ovoid, and a rectangle to threedimensional forms, and even any two-dimensional figure to three-dimensional one $\left[\mathrm{K}_{3}\right]$. I can make the drawing of three-dimensional ocean and sea in the social science 
course $\left[\mathrm{K}_{9}\right]$. If we make the model on the table, we cannot do it as we imagined, but with three-dimensional coding which we learned, we can $\left[\mathrm{K}_{1}\right]$. Animations are too funny $\left[\mathrm{K}_{29}\right]$. Coding teaching was so funny. We did beautiful things $\left[\mathrm{K}_{16}\right]$.

There are 4 subthemes placed in the main theme External: transfer, research skill, professional orientation and economizing. It is observed that students who learned through coding are eager to transfer their knowledge and information related to the course to daily life and other lessons. It can be said that visual designs were created by coding and it worked as a propulsive force for reinforcements of both learning and designing new objects, because they were found funny and pleasant by the students. It is also considered that coding teaching made changes in the professional orientation of the students. Moreover, students have stated that these kinds of practices were affordable. The opinions of the students who have had coding training related to the external outcomes are as stated:

I can use what I have learned in technology and design in geometry class $\left[\mathrm{K}_{1}\right]$. There is a cube in that class. I can make use of the knowledge in mathematics, science and other classes $\left[\mathrm{K}_{10}\right]$. I can transfer to my daily life what I learned in coding $\left[\mathrm{K}_{12}\right]$. Our research skill is improved $\left[\mathrm{K}_{17}\right]$. Coding has an effect on the choice of profession in the future $\left[\mathrm{K}_{24}\right]$. Coding has many privileges $\left[\mathrm{K}_{11}\right]$. It can help in every profession $\left[\mathrm{K}_{18}\right]$. You can make limitless designs with coding $\left[\mathrm{K}_{26}\right]$. Making use of coding in technology and design course has contributed a lot. For instance, my choice of profession has changed $\left[\mathrm{K}_{3}\right]$. Producing a project is much better than to buy materials, therefore, it has economic aspects and saves time. We don't waste time and we can rectify possible mistakes $\left[\mathrm{K}_{29}\right]$. We cannot build up a model if it is broken; even if we rebuild it, it would be costly $\left[\mathrm{K}_{13}\right]$. We can use this coding in robot construction so we can move the robot $\left[\mathrm{K}_{14}\right]$. We can share our projects on the Internet and encourage ourselves and our environment to make projects $\left[\mathrm{K}_{24}\right]$.

\section{Discussion}

This research examined the effects of coding using Scratch program as an instrument on the studnets' visual-spatial reasoning skills in technology and design course. With regards to the aim of the study, the results of the visual-spatial reasoning test consisting of three parts - rotating in mind, spatial discernment and analysis, depth perception and complementation in mind - were improved. Effectiveness and permanency of traditional technology and design course and of innovative technology and design course revised with coding were tested in the experimental pattern. It was determined that post-test and permanency test results of visual-spatial reasoning skill of the students in the experimental group were significantly different from the ones of students in the control group. According to this result, it can be said that the curriculum of the technology and design course revised with Scratch coding program was efficient in improving the experimental group students' visual-spatial reasoning skills in dimensions rotating in mind, depth perception, spatial discernment and analysis. These results show 
similarity with other studies in literature: in the research on middle school students by Dere (2017), significant differences in favour of students from the experimental group were determined in spatial visualization skills, imagination in mind, intersecting surfaces of the objects and skills of rotating the forms in mind; Septia et al. (2018) found out that their interactive multimedia instruction was effective on mental rotation, spatial orientation and spatial visualization; in another research it was concluded that activities based on geometrical and mechanical games were efficient in improving spatial thinking skills of students of middle schools (Demirkaya \& Masal, 2017). Jones and Burnett (2008) found out that there was a correlation between mental rotation ability and computer programming. Heng et al. (2014) designed a spatial game to enhance students' spatial orientation and memory, so they found out that this game was an efficient method of enhancing students' spatial orientation and memory in a short time period. Çalışkan (2016), who implemented the test of rotating in mind in the experimental pattern, has revealed that making use of dynamic geometry software in the process of teaching solid bodies in the curriculum of mathematics supported students' learning experiences and improved their spatial thinking. Students in this research have stated that the curriculum revised with coding teaching has a positive effect on spatial contents as imagining objects, perception of depth and discernment features. Also, this new curriculum supported with coding, focused on students and different from the traditional educational approaches, was viewed as a funny, pleasant and improving process. In addition to this, many studies showed that coding and/or computer programming have positive effects on students' learning. It is claimed that students have perceived computer programming as an enjoyable and attractive learning activity (Fessakis et al. 2013; Liao \& Bright, 1991). Moreover, Fessakis et al. (2013) found out that students' mathematical skills, communication skills and collaboration skills have increased in Logo computer programming setting. Students who were motivated and have had positive attitudes towards the course were more active in creating new ideas, improving new projects and deepening their imagination. In the qualitative dimension of this research, it was revealed that students in the experimental group have had positive attitudes toward the course and had higher motivation. It was considered that the post-test scores, permanency test scores and motivation of the students were higher in the experimental group than the control group, which wasthe result of functionality of the new program supported with coding. Therefore, the proposed curriculum in this research can be assessed as applicable and sustainable. A similar study was performed with seventh-grade students by Kalay (2015) where the educational setting was supported with Cabri 3D - dynamic geometry software. It was observed that this setting generated a significant difference in spatial orientation skills of students in the experimental group. In addition to this, it was determined that students have had positive attitudes directed to computer-supported settings. The study of Howland and Good (2015) confirmed that students were highly motivated to produce their own games with Flip program, which is a graphics programming 
language. Most of the students could write a small program which triggered interactive behaviors. Topaloğlu (2011) conducted a research on visualizing skills of students of secondary education. A significant increase was determined of the students' spatial thinking when using Cabri 3D program in the research. Students in the experimental group have produced their projects and presented designs of their imaginations with the use of computer-aided animations. It was considered that visually supported learning activities have had a positive influence on the permanency of learning. The study by Gunay (2015) determined a significant relationship between spatial skills and animation. These findings are in compliance with the students' opinions on using spatial skills, implementation and transfer themes in the qualitative dimension of our research. The research by Francis et al. (2016) found that learning by doing and living has a more positive effect on spatial reasoning than the talking - listening technique. It was found from the hand signals of students during the programming process that there were possibilities to increase their spatial reasoning skills on an improved and complex level by their educational experiences. These conclusions are in sync with the opinions of students stated in themes of implementation, making use of spatial skills, and of psychomotor skills in the qualitative dimension of our study. Furthermore, the results of Saltan and Kara's (2016) research on the facilitating feature of Scratch coding program for visualizing and computational thinking are in concurrence with the opinion of students about the Scratch program. Ada's study (2016) determined that the brain-based learning program increased the participants' spatial skills.

The other dimension which emerged in the qualitative dimension of the research was efficiency of the technology and design course renewed with coding when it comes to high-level cognitive competencies as analysis, synthesis and evaluation, according to Bloom's taxonomy. The students stated they gained positive learning experience in reasoning, linking visual-spatial items, discerning similar and different items, imagining depths and dimensions. This was considered important for transferring knowledge and learning into daily life. It was determined that enriched learning and teaching experiences of the students with computer software significantly increased their spatial skill in the study of Özlü (2014). Akbay (2015) has determined that spatial visualization achievement of the experimental group was increased in his study conducted in the Minecraft game setting. In a similar way, our study, which used the Scratch programme, determined the positive effects on the scores of the post-test and permanency test of using spatial skills such as rotating in mind, depth perception and completing in mind, and the attitudes of the students about the implementation. In the qualitative dimension of the study, the students stated there is an increase in the understanding level of mathematics and geometry, and they wanted to create learning experiences supported by coding in other courses. Some of the students stated that they implemented the Scratch program to Science and English courses. It was considered important for them to transfer the learning experiences of technology and design course supported with coding to other courses. Gül (2014), Gül and Karataş (2015), Batdal Karaduman 
(2012), and Kök (2012) have all determined a positive relationship between spatial abilities and understanding geometry in a similar way. The results of these researches comply with the opinions of students about spatial skills and transfer themes stated in the qualitative dimension of the research. On the other hand, it is considered that most of the studies conducted about spatial skills were focused on the fields of mathematics, geometry and information technologies. However, there are many different disciplines such as technology and design where spatial skills are used extensively. However, it is obvious that research on technology and design course is scarce. One of the rare researches on this issue is a study conducted by Charcharos et al. (2015) where a test was developed for using spatial thinking in the field of geography. Furthermore, in the traditional teaching method learning takes place at the level of knowledge and comprehension. On the other hand, there is evidence that learning with the use of student-centered, project-based and learning-by-living methods is more focused on skills, entrepreneurship and innovation. In this context, it is determined that coding, which is one of the digital learning tools with an innovative interface, will be among the priorities of advanced education systems with regard to student learning and shaping the future (OECD, 2017).

The results of the studies in literature have proved that experimental implementations have a greater effect on student learning. This research demonstrated the positive effect of coding teaching supported by the Scratch program in technology and design course on visual-spatial reasoning skills of the students from the experimental group. The qualitative results of the research also proved that coding teaching supported students' learning. According to the opinions of the students, coding teaching supported their learning, increased motivation, and improved visual-spatial reasoning skills. This result requires a course activity such as Technology and Design, with an apparent innovative dimension, be handled in a multidimensional way. As the algorithmic software and coding will come to the forefront in building the future and establishing strong economic structures, the introduction of the course programs enabling students to step into the world of coding becomes a subject to be considered by today's educational systems and their policymakers. The debate on coding in the curricula of innovative school systems tends to be present more and more each day. In this context, developing students' visual - spatial intelligence with coding opens a perspective of students prepared for the future, people beyond the school system that only theaches how to code.

\section{Conclusion and suggestions}

The easiest way to gain skills for an individual is through education. Developed educational systems are oriented to doing/experiencing learning models focused on the student, with the goal of enriching learning experiences. Progress and development depend on educational systems that prioretise supported learning experiences with computer and information technologies which accentuate the 21st century skills. The common feature of advanced educational systems is their emphasis on high-quality 
structure, innovation and entrepreneurship. In this study, the algorithmic software and coding accepted among the distinguished future professions were introduced. It has been shown that the acquisition level and permanency of the course is higher for the students who experienced coding integrated with the technology and design course by doing and experiencing. It has been determined that coding teaching enhanced cognitive high-level skills, supported student spatial skills, and enabled transfer of knowledge to other courses, as the students were provided with opportunities to produce new projects which increased their motivation for the course. From this point forth we recommend the implementation of coding into the technology and design course, encouragement of coding by transferring coding experiences to other courses, development of spatial reasoning tests for sixth and eighth classes in order to obtain the necessary measurements. In addition, we recommend this research be used as a resource in the curriculum development studies, especially in developing technology and design course curriculum and coding education in the Turkish Republic of Northern Cyprus.

This study offers a teaching program based on the needs analysis which will hopefully be a reference for the development of the prevailing traditional technology and design course teaching in Northern Cyprus. Technology and design courses should be restructured with other subjects to respond to the requirements of the domestic market and the 21-century skills. The necessity of coding in technology and design courses is crucial for sustaining the subject. A program responding to the interests and expectations of Generation Z should be designed. We recommend that both technology and design course and information and communication technology course be combined into one. Technology and design, and coding teaching implementations may start in primary education. It is advised that this research is referred to in designing the programs for technology and design courses and information and communication technologies. In order to confirm the effect of coding on self-efficacy, researches should be done on advanced levels. Different programs can be designed using different coding programs to support this study done with the use of Scratch, and their results put forth.

In order to make the technology and design course more functional, it is expected the course be integrated with information and communication technologies, or these two subjects to be integrated and evaluated in a different context, such as STEM. This study also encourages teachers of these subjects to utilize new techniques and undergo training in coding. It is expected of this study to help administrators who determine educational strategies and scenarios for digital abilities to come to the forefront. It is thought that this study may also have some implications for policymakers in education who will make this course more functional and integrate it with ICT skills. 


\section{References}

Ada, K. (2016). Beyin temelli öğrenme kuramına yönelik tasarlanan eğitim ortamında 7. Sınıf ögrencilerinin uzamsal becerilerinin incelenmesi. (Unpublished master's thesis). Recep Tayyip Erdoğan Üniversitesi, Sosyal Bilimler Enstitüsü, Rize.

Akbay, M. (2015). Kurmacılık yaklaşımı ile dijital oyun ortamında tasarım yapmanın, lise ögrencilerinin geometri başarı, öz yeterliklerine ve uzamsal becerilerine etkisi. (Unpublished master's thesis). Atatürk Üniversitesi, Eğitim Bilimleri Enstitüsü, Erzurum.

Akpınar, Y., \& Altun, A. (2014). Bilgi toplumu okullarında programlama eğitimi gereksinimi. İlköğretim online, 13(1), 1-4. http://ilkogretim-online.org.tr/index.php/io/article/view/2099

Atasoy, R., Güçlü, N. (2020). Evaluation of numeracy skills of adults according to the results of PIAAC 2015 in Turkey. World Journal of Education, 10(2), 1-123.

Batdal Karaduman, G. (2012). İlköğretim 5. sınıf üstün yetenekli öğrenciler için farklılaştırılmış geometri öğretiminin yaratıcı düşünme, uzamsal yetenek düzeyi ve erişiye etkisi. (Unpublished doctoral thesis), İstanbul Üniversitesi, Sosyal Bilimler Enstitüsü, İstanbul.

Brown, G., Irving, E., \& Keegan, P. (2008). An introduction to educational assessment, measurement and evaluation. Pearson Prentice Hall Rosedale.

Büyüköztürk, Ş., Çakmak, E.K., Akgün, Ö.E, Karadeniz, Ş., \& Demirel, F. (2016). Bilimsel Araştırma Yöntemleri. Pegem Akademi.

Calder, N., \& Taylor, M. (2010). Scratching below the surface: Mathematics through an alternative digital Lens? Shaping the future of mathematics education: Proceedings of the 33rd annual conference of the Mathematics Education Research Group of Australasia (s. 117-124). Fremantle: Mathematics Education Research Group of Australasia.

Calao, L.A., Correa, H.E., Leon, J.M., \& Robles, G. (2015). Developing mathematical thinking with scratch: An experiment with 6th grade students. Springer International Publishing, 17-27. DOI: 10.1007/978-3-319-24258-3_2

Campbell, D.T., \& Stanley, J.C. (1963). Experimental and quasi experimental designs for research, Houghton Mifflin Company.

Charcharos, C., Tomai, E., \& Kokla, M. (2015). Assesing spatial thinking ability. GEOTHNK International Closing Conference (s. 151-166). doi: 10.13140/RG.2.1.1621.0962.

Choi, B., Jung, J., \& Baek, Y. (2013). In what way can technology enhance student learning?: A preliminary study of Technology Supported learning in Mathematics. In R. McBride \& M. Searson (Eds.). Proceedings of Society for Information Technology \& Teacher Education International Conference 2013 (pp.3-9). Association for the Advancement of Computing in Education (AACE). https://www.learntechlib.org/primary/p/48061/

Çağıltay, E. N., \& Fal, M. (2015). Scratch ile programlamayı öğreniyorum. ODTÜ Yayıncılık. Clement, D., \& Batista, M. (1992). Handbook of research on mathematics teaching and learning: Geometry and spatial reasoning. MacMillan Publishing Company.

Creswell, J.W. (2014). Research design qualitative, quantitative, and mixed methods approaches (4 b.). SAGE.

Cox, A., Fisher, M., \& O’Brien, P. (2005). Theoretical considerations on navigating codespace with spatial cognition. In P. Romero, J. Good, Acosta Chaparro, E., \& S. Bryant (Eds.), Proceedings of the 17th Workshop of the Psychology of Programming Interest Group (pp. 92-105). 
Çalışkan, M. (2016). Katı cisimlerin öğretiminde dinamik geometri yazılımı destekli öğretimin 7. sını öğrencilerinin geometriye yönelik tutumuna ve uzamsal düşünmelerine etkisinin araştırılması. (Unpublished master's thesis). Dokuz Eylül Üniversitesi, Eğitim Bilimleri Enstitüsü, İzmir.

Demirkaya, C., \& Masal, M. (2017). Geometrik-Mekanik Oyunlar Temelli Etkinliklerin Ortaokul Öğrencilerinin Uzamsal Düşünebilme Becerilerine Etkisi. Sakarya University Journal of Education, 7(3), 600-610.

Demirer, V., \& Sak, N. (2016). Programming education and new approaches around the world and in Turkey. Eğitimde Kuram ve Uygulama, 12 (3), 521-546.

Demir, A.Ö. Çocuğunuza kod yazmayı öğretin. Harvard Business Review Türkiye. 2017. https:// hbrturkiye.com/blog/cocugunuza-kod-yazmayi-ogretin.

Gold, A.U., Pendergast, P.M., Ormand, C.J., Budd, D.A., Stempien, J.A., Mueller, K.J., \& Kravitz, K.A. (2018). Spatial skills in undergraduate students-Influence of gender, motivation, academic training, and childhood play. Geosphere, 14(2), 668-683, doi:10.1130/GES01494.1.

Erol, O., \& Kurt, A. A. (2017). The effects of teaching programming with scratch on preservice information technology teachers' motivation and achievement. Computers in Human Behavior, 11-18. https://doi.org/10.1016/j.chb.2017.08.017

European Schoolnet. (2014). Computing our future computer programming and codingpriorities, school curricula and initiatives across Europe. Durando, M.(Ed). http://www. eun.org/

Fee, S. B., Minkley, A.M.H., \& Lombardi, T.E. (2017). New directions for computing education embedding computing across disciplines. Springer (e-book) https://www.springer.com/la/ book/9783319542256

Fessakis, G., Gouli, E., \& Mavroudi, E. (2013). Problem-solving by 5 - 6 years old kindergarten children in a computer programming environment: A case study. Computers \& Education, 63, 87 - 97.doi:10.1016/j.compedu.2012.11.016

Flannery, L.P., Silverman, B., Kazakoff, E.R., Bers, M.U., Bonta, P., \& Resnick, M. (2013). Designing ScratchJr: Support for early childhood learning through computer programming. Interaction Design and Children Conference (p. 1-10). Interaction Design Foundation. http:// ase.tufts.edu/DevTech/publications/scratchjr idc 2013.pdf

Francis, K., Khan, S., \& Davis, B. (2016). Enactivism, spatial reasoning and coding. Digital Experiences in Mathematics Education, 2, 1-20.

Friend, M., Matthews, M., Winter, V., Love, B. Moisset, D., \& Goodwin, I. (2018). Bricklayer: Elementary students learn math through programming and art. SIGCSE'18 conference, Doi: $10.1145 / 3159450.3159515$

Gardner, H. (2004). Zihin Çerçeveleri Çoklu Zeka Kuramı. Ebru Kılıç (Translate.). Alfa Yayınları.

Gamst, G., Meyers, L. S., \& Guarino, A.J. (2008). Analysis of variance designs: A conceptual and computational approach with SPSS and SAS. Cambridge University Press.

Gül Yıldırım, Ç., \& Karataş, İ. (2015). 8. Sınıf Öğrencilerinin Dönüşüm Geometrisi Başarılarının Uzamsal Becerileri, Geometri Anlama Düzeyleri ve Matematiğe Yönelik Tutumları Arasındaki İlişkinin İncelenmesi. Karaelmas Journal of Educational Sciences, 3, 36-48. 
Günay, F. (2015). Fen Bilgisi Bölümü Öğretmen Adaylarının 3 Boyutlu Sanal Ortamlardaki Etkileşim Düzeyleri, Uzamsal Yetenekleri ve Başarıları Arasındaki İlişkilerin İncelenmesi. (Unpublished master's thesis). Atatürk Üniversitesi Eğitim Bilimleri Enstitüsü, Erzurum Halpern, D. F. (2000). Sex differences in cognitive abilities. Lawrence Erlbaum Associates.

Hartatiana, H., Darhim, H., \& Nurlaelah, E. (2018). Improving junior high school students' spatial reasoning ability through model eliciting activities with cabri $3 \mathrm{~d}$. International Education Studies, 11(1), 148-154. https://doi.org/10.5539/ies.v11n1p148

Hegarty, M., \& Kozhevnikov, M. (1999). Types of visual-spatial representations and mathematical problem solving. Journal of Educational Psychology, 91(4), 684-689. http:// dx.doi.org/10.1037/0022-0663.91.4.684

Heng, C.L., Min, C. C., \& Chiung, Y. L., (2014). Developing spatial orientation and spatial memory with a treasure hunting game. Educational Technology \& Society, 17(3), 79-92.

Henning K. (2018) How artificial intelligence changes the world. In: Karafillidis A., Weidner R. (eds.). Developing Support Technologies. Biosystems \& Biorobotics, vol 23. Springer, Cham. Doi://doi.org/10.1007/978-3-030-01836-8_27

Heppner, P. P., Kivlighan, D. M. J., \& Wampold, B. E. (1999). Research design in counseling (2nd ed.). Wadsworth.

Howland, K., \& Good, J. (2015). Learning to communicate computationally with Flip: A bimodal programming language for game creation. Computers \& Education, 80, 224-240. https://doi.org/10.1016/j.compedu.2014.08.014

Jakoš, F., \& Verber, D. (2017). Learning basic programming skills with educational games: A case of primary schools in Slovenia. Journal of Educational Computing Research, 55(5), 673-698. https://doi.org/10.1177/0735633116680219

Jones, S., \& Burnett, G. (2008). Spatial ability and learning to program. Human Technology, 4(1), 47-61. Doi: 10.17011/ht/urn.200804151352

Kabakçı, A., \& Demirkapı, A. (2016). İzmit Bilim Sanat Merkezinde Uygulanan “Matematik ve Sanat” Dersi Etkinlik Uygulamalarının Öğrencilerin Uzamsal Yetenekleri Üzerine Etkisi. Hasan Ali Yücel Eğitim Fakültesi Dergisi, 13 (1).

Kalay, H. (2015). 7. Sınıf öğrencilerinin uzamsal yönelim becerilerini geliştirmeye yönelik tasarlanan öğrenme ortamının değerlendirilmesi, (Unpublished master's thesis). Karadeniz Teknik Üniversitesi, Eğitim Bilimleri Enstitüsü, Trabzon

Kalelioğlu, F. (2015). A new way of teaching programming skills to K-12 students: Code. org. Computers in Human Behavior. 200-210. http://dx.doi.org/10.1016/j.chb.2015.05.047

Kanaki, K., \& Kalogiannakis, M. (2018). Introducing fundamental object-oriented programming concepts in preschool education within the context of physical science courses. Education and Information Technologies. 23(6), 2673-2698. https://doi.org/10.1007/s10639-0189736-0

Kök, B. (2012). Üstün zekalı ve yetenekli öğrencilerde farklılaştırılmış geometri öğretiminin yaratıcılı̆̆a, uzamsal yeteneğe ve başarıya etkisi. (Unpublished master's thesis). İstanbul Üniversitesi, Sosyal Bilimler Enstitüsü, İstanbul.

Liao, Y. C., \& Bright, G. W. (1991). Effects of computer programming on cognitive outcomes: A meta-analysis. Journal of Educational Computing Research, 7(3), 251-266. 
Maviş, İ.E. (2010). Avrupa birliği uyum sürecinde teknoloji ve tasarım eğitimi. (Unpublished master's thesis). Gazi Üniversitesi, Fen Bilimleri Enstitüsü, Endüstriyel Teknoloji Eğitimi, Ankara.

McKillup, S. (2012). Statistics explained: An introductory guide for life scientists (Second edition). Cambridge University Press

Miller, R.B., Kelly, G.N., \& Kelly, J.T. (1988). Effects of Logo computer programming experience on problem-solving and spatial relations ability. Contemporary Educational Psychology, 13(4),348-357. https://doi.org/10.1016/0361-476X(88)90034-3

Miller, R. G. (1969). Simultaneous statistical inference. McGraw-Hill.

Mumcu, H.Y., \& Yıldız, S. (2015). Uzamsal Düşünmeyi Destekleyici Web-Tabanlı Öğretim Materyali Geliştirme. Uyulama ve Değerlendirme, Elementary Education Online, 14(4): 1290-1306

OECD (2017), Education at a Glance 2017: OECD Indicators, OECD Publishing, Paris. http://dx.doi.org/10.1787/eag-2017-en

Olkun, S., \& Altun, A. (2003). İlköğretim Öğrencilerinin Bilgisayar Deneyimleri ile Uzamsal Düşünme ve Geometri Başarıları Arasındaki İlişki. The Turkish Online Journal of Educational Technology, 2 (4), Article 13.

Özden, C., Atasoy, R. (2019). Determination of educational needs of technology and design courses in secondary school students. International Online Journal of Education and Teaching (IOJET), 6(3), 513-525.

Özlü, T. (2014). Bilgisayar yazılımları aracıliğıyla oluşturulan 3-d sanal ortamların yatılı okullarda eğitim alan öğrencilerin uzamsal yeteneklerine etkisinin incelenmesi. (Unpublished master's thesis). Kırıkkale Üniversitesi Fen Bilimleri Enstitüsü, Kırıkkale

Popat, S., \& Starkey, L. (2019). Learning to code or coding to learn? A systematic review, Computers \& Education, 128, 365-376. https://doi.org/10.1016/j.compedu.2018.10.005

Rososzczuk, R. (2015). Application of Cabri 3D in teaching stereometry. Advances in Science and Technology Research Journal, 9(26), 148-151. Doi: 10.12913/22998624/2382

Saltan, F., \& Kara, M. (2016). ICT teachers' acceptance of "scratch" as algorithm visualization software. Higher Education Studies, 6(4), 146-155. http://dx.doi.org/10.5539/hes.v6n4p146

Sanjanaashree, P., Anand K.M., \& Soman, K.P. (2014). Language learning for visual and auditory learners using scratch toolkit. 2014 Computer Communication and Informatics International Conference on (s. 1-5). Coimbatore: IEEE doi: 10.1109/ICCCI.2014.6921765

Sayın, Z., \& Seferoğlu, S.S. (2016). Yeni Bir 21. Yüzyıl becerisi olarak kodlama eğitimi ve kodlamanın eğitim politikalarına etkisi. XVIII Akademik Bilişim Konferansı- AB 2016. Aydın. http://yunus.hacettepe.edu.tr/ sadi/yayin/AB16 Sayin-Seferoglu Kodlama.pdf

Sencan, H. (2005). Reliability and validity in social and behavioral measures. Ankara.

Septia, T., Prahmana, R.C.I., Pebrianto, P., \& Wahyu, R. (2018). Improving students spatial reasoning with course lab. Journal on Mathematics Education, 9(2), 327-336.

Serpe, R. L. (2017). Gamification through algebraic coding, (Education and Human Development Master's Theses). College at Brockport, State University of New York, New York.

Stevens, J.P. (2009). Applied multivariate statistics for the social sciences. 5th Edition, Routledge. 
Tabachnick, B. G., \& Fidell, L.S. (2013). Using multivariate statistics (6 ed.). Pearson Education Limited.

Taylor, M., Harlow, A., \& Forret, M. (2010). Using a computer programming environment and an interactive whiteboard to investigate some mathematical thinking. Procedia Social and Behavioral Sciences, 8, 561-570. https://doi.org/10.1016/j.sbspro.2010.12.078

Topaloğlu, İ. (2011). Cabri 3 d ile yapılan ders tasarımlarının öğrencilerin uzamsal görselleme ve başarılarına etkisinin incelenmesi, (Unpublished master's thesis). Marmara Üniversitesi/ Eğitim Bilimleri Enstitüsü, İstanbul.

Tuğun, V., Uzunboylu, H., \& Ozdamli, F. (2017). Coding education in a flipped classroom. TEM Journal, 6(3), 599-606.

Turgut, M. (2007). İlköğretim II.kademede öğrencilerin uzamsal yeteneklerinin incelenmesi, (Unpublished master's thesis). Dokuz Eylül Üniversitesi, Eğitim Bilimleri Enstitüsü, İzmir.

Wai, J., \& Kell, H.J. (2017) What innovations have we already lost?: The importance of identifying and developing spatial talent. In: Khine M. (eds) Visual-spatial Ability in STEM Education. Springer.

Webb, N. M. (1984). Microcomputer learning in small groups: Cognitive requirements and group processes. Journal of Educational Psychology, 76, 1076-1088.

Wing, J. M. (2006). Computational thinking. Communications of the ACM, 49(3), 33-35. $\underline{10.1145 / 1118178.1118215}$

Winter, V., Love, B., \& Corritore, C. (2018). The art of the Wunderlich cube and the development of spatial abilities, International Journal of Child-Computer Interaction, 18, 1-7, https://doi. org/10.1016/j.ijcci.2018.03.003

Yıldırım, A., \& Şimşek, H. (2011). Sosyal bilimlerde nitel araştırma yöntemleri. Seçkin yayıncılık. Ankara

Yolcu, B. (2008). Altıncı sını öğrencilerinin uzamsal yeteneklerini somut modeller ve bilgisayar uygulamaları ile geliştirme çalışmaları, (Unpublished master's thesis). Eskişehir Osmangazi Üniversitesi, Fen Bilimleri Enstitüsü, Eskişehir

Yükseltürk, E., \& Altiok, S. (2016). An investigation of the effects of programming with scratch on the preservice IT teacher's self-efficacy perceptions and attitudes towards computer programming. British Journal of Educational Technology, 48(3), 789-801, https:// doi.org/10.1111/bjet.12453

Yüksel, N. S. (2013). Uzamsal yetenek, bileşenleri ve uzamsal yeteneğin geliştirilmesi üzerine. (Unpublished doctoral thesis). Hacettepe Üniversitesi, Fen Bilimleri Enstitüsü, Ankara.

\author{
Ramazan Atasoy \\ Turkey Ministry of National Education \\ atasoyramazan@gmail.com \\ Celalettin Özden \\ Turkey Ministry of National Education \\ cozden2001@gmail.com
}




\section{Učinak kodiranja na vještine vizualno-prostornoga mišljenja učenika}

\section{Sažetak}

Cilj je ovoga rada istražiti učinke upotrebe kodiranja u nastavi tehnologije $i$ dizajna na vještine vizualno-prostornoga mišljenja učenika. U studiji je korišten sekvencijalni eksperimentalni dizajn i miješane istraživačke metode. Kvantitativna dimenzija istraživanja provedena je na nasumičnom eksperimentalnom uzorku s provedbom pred-i posttesta u kontrolnoj skupini, a u kvalitativnoj dimenziji istraživanja korištena je tehnika intervjua. Uzorak ispitanika uključivao je učenike srednje škole Şehit Hüseyin Ruso iz Nicosiae u Sjevernom Cipru, u školskoj godini 2016./2017. Test vizualno-prostornoga mišljenja koji je razvio istraživač korišten je za prikupljanje kvantitativnih podataka, a polustrukturirani intervju za dobivanje kvalitativnih podataka. T-test za nezavisne uzorke, Cohenov d koeficijent veličine učinka i dvosmjerna analiza varijance korišteni su za analizu kvantitativnih podataka. Analiza sadržaja primijenjena je u obradi kvalitativnih podataka. Utvrđeno je da su vještine prostornoga mišljenja učenika koji su koristili kodiranje značajno različite od onih učenika koji nisu koristili kodiranje - eksperimentalna skupina ima pozitivan stav prema nastavi i korištenju vlastitih kognitivnih, senzornih i psihomotoričkih vještina na visokoj razini. Može se zaključiti da je kodiranje važan čimbenik za razvijanje vještina vizualno-prostornoga mišljenja učenika u ovom kontekstu.

Ključne riječi: kodiranje; obrazovanje; programski jezik Scratch; vještine; vizualnoprostorno mišljenje

\section{Uvod}

Pretpostavlja se da je kodiranje, vrlo popularno u polju informatike današnjega svijeta, odlučujući faktor u obrazovanju pojedinaca koji trebaju zadovoljiti rastuće potrebe u području programske podrške u svijetu budućnosti (Sayın i Seferoğlu, 2016). Znanstveni i tehnički napredak pomaže i daje nove prilike za poučavanje i poboljšanje okoline učenja (Rososzczuk, 2015). Oblikovanje iskustava učenja usmjerenih na kodiranje od predškolske dobi i njihova primjena unutar okruženja za učenje (ILI obrazovnog okruženja) u razvijenim odgojno-obrazovnim sustavima pokazatelj su važnosti ovoga 
pitanja (Akpınar i Altun, 2014). Transformacija odgojno-obrazovnih sustava postala je nužna unutar ove paradigme gdje se internet stvari (u eng. bi trebalo biti Internet of things) promatra kroz prizmu ekonomski orijentiranih trendova kao što su Industrija 4.0 i Društvo 5.0 (Atasoy i Güçlü, 2020). Ova prenamjena vještina koja se očekuje od učenika u 21. stoljeću potencijalno može utjecati na njihovu buduću profesionalnu orijentaciju. Pokazateljem navedene promjene može se smatrati i činjenica da roboti, čije se funkcioniranje temelji na umjetnoj inteligenciji, postupno preuzimaju našu svakodnevicu i zamjenjuju ljude koji su izmislili i upravljaju strojevima (Henning, 2018). Brze razvojne promjene u području robotike imat će smisla u integraciji s programskom podrškom koja će omogućiti upotrebu novih mehaničkih i digitalnih tehnologija u tu svrhu. Kako bi se zadovoljile spomenute potrebe za programskom podrškom, obrazovanje u području kodiranja počelo je prodirati u učenička obrazovna iskustva od rane dobi. Code Org., Cod Club, CoderDojo, Scratch, Alice itd. samo su neke su od internetskih aplikacija i programa kodiranja koji omogućuju slobodnu upotrebu (Demirer i Sak, 2016). U SAD-u i većini europskih država kodiranje je nastavni predmet, dok se u ostalim zemljama provode potrebna nastojanja za uključivanje kodiranja u kurikul (Europska školska mreža, 2014). Od 2013. godine započela je interdisciplinarna nastava i obrazovanje usmjereno na učenike i učitelje u mnogim regijama Južne Koreje, Britanije, Francuske i Sjedinjenih Američkih Država (Demirer i Sak, 2016).

Kodiranje je bitan programerski posao. Računalno programiranje je proces prevođenja jednostavnih ili složenih podataka na računalni jezik uz pomoć algoritama i brojeva 1 i 0 . Računalno programiranje je složen proces koji zahtijeva sposobnosti učenja najvišega stupnja. Kako bi se prevladale teškoće i približilo obrazovanje u području programiranja osobama relativno mlade dobi, nastava kodiranja uvodi se u obrazovni kurikul zemalja sa Scratch i sličnim programima (Çă̆lltay i Fal, 2015). Algoritamski sadržaj nastave kodiranja doprinosi razvoju vještina računalnoga mišljenja učenika (Taylor i sur., 2010). U isto vrijeme kodiranje doprinosi razvoju vještina refleksivnoga i kreativnoga mišljenja pojedinaca, njihovim vještinama rješavanja problema u tehnološki razvijenim okruženjima i prirodnom razvoju jezika (Flannery i sur., 2013; Sanjanaashree i sur., 2014). Štoviše, postoje istraživanja koja pokazuju da kodiranje doprinosi kognitivnim vještinama višega reda poput analize, sinteze, evaluacije, sposobnosti primjene i prenošenja znanja u praksu i prostornoga mišljenja (Akpınar i Altun, 2014; Demirer i Sak, 2016; Miller i sur, 1988). Korištenjem kodiranja učenici također imaju priliku prenijeti znanje i vještine iz jednoga u drugo područje (Fee i sur., 2017; Winter et al., 2018).

Vještine digitalne pismenosti među najvažnijima su za učenike u 21. stoljeću, nakon osnovnih vještina procesiranja (Popat i Starkey, 2019; Wing, 2006). Kodiranje i programiranje omogućuje nam sudjelovanje u globalnom natjecanju i stvaranje visoko kvalitetnih proizvoda dodane vrijednosti. Steve Jobs također svima preporučuje računalno programiranje i kodiranje. Prema ovom stavu, kodiranje ili programiranje je znak koji će ostaviti trag na vještinama 21. stoljeća (Demir, 2017). Stoga je potrebno 
razvijati digitalne okoline učenja, pronaći mjesto za kodiranje u novim obrazovnim pristupima, pozicionirati digitalne vještine tijekom revizije kurikula te podržati računalno obrazovanje, kako bi isto prešlo u široku upotrebu u poučavanju kodiranja (Kanaki i Kalogiannakis, 2018).

Može se primijetiti da je kodiranje uvedeno u različite discipline i u osmišljavanje različitih obrazovnih okolina. Kodiranje koje omogućuje prenošenje znanja i interdisciplinarna iskustva ima potencijal razvijanja prostorne sposobnosti. Neka od istraživanja kodiranja u literaturi su sljedeća: Friend i sur. (2018) ispitivali su učenje matematike uz pomoć kodiranja i umjetnosti; Erol i Aşkım Kurt (2017) te Tugun i sur. (2017) istraživali su učinak Scratch programa na motivaciju učenika; Kalelioğlu (2015) je ispitivao učinak kodiranja na vještine rješavanja problema, a Calder i Taylor (2010) istraživali su interakciju upotrebe Scratch programa i matematičkih vještina; Fessakis i sur. (2013) usredotočili su se na kompetencije za razvoj mišljenja višega reda i vještine rješavanja problema upotrebom algoritama studenata predškolskoga odgoja uz pomoć računalnoga programiranja; Taylor i sur. (2010) istraživali su utjecaj kodiranja na oblikovanje budućnosti matematike; Choi i sur. (2013) ustanovili su da kodiranje zasnovano na tehnologiji unapređuje poučavanje matematike; Calao i sur. (2015) analizirali su utjecaj kodiranja sa Scratch programom na vještine matematičkoga mišljenja; Saltan i Kara (2016) proveli su istraživanje u kojem su utvrđivali smatraju li učitelji računalne tehnologije da Scratch program pruža mogućnost algoritamske vizualizacije; Yükseltürk i Altık (2016) istraživali su stavove o programiranju i kodiranju; Serpe (2017) je istraživao učinak poučavanja matematike uz upotrebu igara u kodiranju. Navedene studije svjedoče važnosti istraživanja polja digitalne pismenosti $\mathrm{s}$ intenzivnim $\mathrm{i}$ istaknutim korištenjem vizualno-prostornih vještina.

Novija istraživanja otkrivaju vještine vizualnoga i prostornoga mišljenja kao temeljne kompetencije koje igraju važnu ulogu u mnogim disciplinama, posebno matematici i znanosti (Winter i sur., 2018). Vizualno-prostorna sposobnost može se definirati kao kognitivna osobina koja označava sposobnost konceptualizacije prostornih odnosa između predemta (Clement i Battista, 1992; Halpern, 2000). Vizualnoprostorna inteligencija je vrsta sposobnosti nužna u mnogim poljima poput navigacije u stvarnom svijetu, pronalaženja smjera u svakodnevnom životu, osmišljavanja interijera i eksterijera, aktivnostima popravljanja i sportskim aktivnostima (Cox i sur., 2005; Jones i Burnett, 2008; Yüksel, 2013). Osnova vizualno-prostornih vještina je točna percepcija vizualnoga svijeta. Učenici razvijenih vizualno-prostornih vještina sposobni su oblikovati vlastite percepcije, kreativno ih preoblikovati i stvoriti vizualno iskustvo bez fizičkoga podražaja. Ipak, ne smijemo previdjeti da sve ostale osobine koje razotkriva Gardner (2004) u teoriji višestrukih inteligencija imaju potencijal međusobnoga utjecaja. Prostorne sposobnosti uključuju sposobnost vizualizacije predmeta u prostoru, njihovog definiranja iz različitih očišta ili pomicanje njihovih dijelova odvojeno. Prostorna sposobnost definira se kao sposobnost promjene i korištenja predmeta i njihovih dijelova u dvodimenzionalnim i trodimenzionalnim prostorima 
(Kabakçı i Demirkapı, 2016). Navode se dvije poddimenzije prostorne sposobnosti - prostorni odnosi i prostorna vizualizacija (Olkun i Altun, 2003). Prostorni odnosi obuhvaćaju odlučivanje o tome koja je skupina predmeta na papiru rotirana. Prostorna vizualizacija uključuje mentalne radnje poput pretvaranja dvodimenzionalnoga u trodimenzionalno kroz mentalno preklapanje ili misaonu integraciju. Iako se za koncept prostorne sposobnosti koriste različiti termini poput prostorne vizualizacije, vizualnoprostorne sposobnosti, prostornoga razumijevanja, trodimenzionalne vizualizacije i prostornoga razmišljanja, gotovo svi oni imaju ista ili slična značenja (Mumcu i Yıldız, 2015). Vizualno-prostorno razmišljanje odnosi se na sposobnost pojedinca da misaono preoblikuje i sintetizira slike predmeta.

Istraživanja prostorne sposobnosti u literaturi nisu jasno određena u smislu koncepta i ekspresije. Ipak, općim terminima može se reći da prostorno mišljenje ima blisku vezu s matematičkim mišljenjem (Olkun i Altun, 2003). Ova tvrdnja potkrijepljena je mnogim radovima (Günay, 2015; Kalay, 2015; Özlü, 2014; Turgut, 2007; Yolcu, 2008). Iako postoje mnoga istraživanja vizualno-prostorne inteligencije u literaturi, većina njih povezana je uz nastavu matematike i geometrije kroz igru (Heng i sur., 2014). Hegarty i Kozhevnikov (1999) istraživali su vrste prostornih predstavki i matematičkoga rješavanja problema; Winter i sur. (2018) istraživali matematičku analizu, kodiranje i prostorno mišljenje; Demirkaya i Masal (2017) ispitivali su odnos između geometrijskih igara i sposobnosti prostornoga mišljenja. Rezultati istraživanja Friend i sur. (2018) pokazuju da su ishodi učenja korištenjem koordinatnih grafova i vizualno-prostorne vještine učenika u značajnoj korelaciji. Gül i Karataş (2015) istraživali su odnos između postignuća u projektnoj geometriji i prostornih vještina. Webb (1984) je također otkrio odnos između prostorne sposobnosti i raznolikih sastavnica programiranja u kratkom tečaju Logo programiranja. Çaliskan i Elliot (2016) istraživali su dinamičnu programsku podršku u području geometrije i njezine utjecaje na vještine prostornoga mišljenja učenika; Rososzczuk (2015), Kalay (2015) i Topaloglu (2011) ispitivali su učinak obrazovne okoline formirane korištenjem programa Cabri 3D na prostorno usmjerenje; Batdal Karaduman i Kök (2012) ispitivali su učinak obrazovnoga programa za nadarenu djecu na prostorne sposobnosti. Hartatiana i sur. (2018) istraživali su aktivnosti učenja uz upotrebu Cabri 3D programa na vještine prostornoga mišljenja u nastavi matematike. U zaključku svojega istraživanja učiteljima matematike su preporučili korištenje programa Cabri 3D. Jakoš i Verber (2016) proveli su istraživanje o učenju vještina programiranja učenika šestih razreda uz upotrebu didaktičkih igara. Prema istraživanju koje su proveli Gold i sur. (2018) o razvoju prostornih sposobnosti studenata geologije, utvrđeno je da igre ili videoigre zasnovane na konstrukciji doprinose razvoju prostornih sposobnosti, obje u školskim obrazovnim programima i izvan školskoga obrazovanja tijekom djetinjstva i adolescencije.

Kodiranje se može integrirati s razvojem vizualno-prostornoga mišljenja u nekoliko točaka. Pri razmatranju sadržaja nastave tehnologije i dizajna pozornost treba usmjeriti na vizualno-prostorne kompetencije učenika. Vizualno-prostorne vještine neizostavni 
su dio dizajniranja tehnološkoga produkta u tom kontekstu. Mnoge obrazovne prakse u današnjim školama nemaju platformu za prezentiranje vještina vizualnoprostornoga mišljenja, a to znači da se mnoge učenike talentirane $u$ tom području ne identificira, ne potiče, niti se isti razvijaju. Zapostavljanje učenika talentiranih u vizualno-prostornom polju uzrokuje ekonomske i socijalne implikacije poput gubitka perspektivnih inovatora i inovacija (Wai i Kell, 2017). Smatra se kako dizajniranje produkta uz upotrebu vizualno-prostornih i informatičkih vještina može utjecati na učenje učenika. Dodatno, okolina za učenje obogaćena računalima, ona koja njeguje radoznalost, interes i motivaciju u učenju može biti koristan alat za razvoj vještina vizualno-prostornoga mišljenja. Zapravo, rezultati analize potreba u poučavanju u nastavi tehnologije i dizajna provedena za potrebe ovoga istraživanja otkrila je da su učeničke obrazovne potrebe uglavnom usmjerene na učenje uz pomoć kodiranja.

Maviş (2010) tvrdi da se nastava tehnologije i dizajna provodi uz upotrebu suportivne računalne tehnologije u SAD-u i zemljama EU. $\mathrm{U}$ tom pogledu i druge zemlje mogu koristiti informacijske tehnologije za poboljšanje iskustava učenja. Stoga, nastava tehnologije i dizajna u Sjevernom Cipru koja je zasnovana na razumijevanju stručnosti intenzivnoga ručnog rada nije dovoljna za učeničko ovaldavanje poljem tehnologije i dizajna niti za razvijanje njihovih vizualno-prostornih sposobnosti. Stoga, nema adekvatnih studija projekata ili programa zasnovanih na obrazovanju u području kodiranja ili tehnologije u Sjevernom Cipru, za razliku od ostatka svijeta (Özden, Atasoy, 2019). Može se reći da je ovo istraživanje primjer koji pokazuje da se nastava tehnologije i dizajna može izvoditi integrirano s nastavom programske podrške, kako bi se zadovoljile potrebe ovih područja. U tom kontekstu, pretpostavlja se da ova studija može pridonijeti razvijanju programa obrazovanja u području kodiranja i tehnologije. Ovaj rad doprinosi polju tehnologije i dizajna u smislu učinaka kodiranja na prostornu inteligenciju. Mnoga su istraživanja povezanosti prostorne sposobnosti i matematike, ali malo je onih koja ispituju prostornu sposobnost i nastavu tehnologije i dizajna. Ovaj rad donekle premošćuje postojeću prazninu i predstavlja interdisciplinarno istraživanje odnosa između kodiranja, prostorne sposobnosti i nastave dizajna i tehnologije.

Ovo istraživanje predstavlja učinke kodiranja na vještine vizualno-prostornoga razmišljanja, koja dolaze u prvi plan pokraj drugih vještina u nastavi tehnologije i dizajna. Nema postojećih studija za razvijanje programa zasnovanih na iskustvu učenja kodiranjem u Sjevernom Cipru. U tom pogledu naglašavamo važnost učinaka kodiranja na učenje učenika i implikacije za razvoj budućih modela učenja kodiranjem i njegovo uključivanje u kurikul. Smatramo kako bi u današnjem digitalnom svijetu, u kojem se sve izvodi na internetu i računalima, integracija kodiranja s nastavom tehnologije i dizajna bila učinkovitija za učenje $\mathrm{Z}$ generacije, tj. djece računala.

\section{Cilj istraživanja}

Ovim istraživanjem nastojalo se ispitati učinak kodiranja na vještine vizualnoprostornoga mišljenja učenika. U tom kontekstu postavljena su sljedeća istraživačka pitanja, kako bi se ostvarili podciljevi istraživanja. 
i. Postoji li značajna razlika između rezultata predtesta vizualno-prostornoga mišljenja između eksperimentalne i kontrolne skupine?

ii. Postoji li značajna razlika između rezultata predtesta, posttesta i testa trajnosti eksperimentalne i kontrolne skupine?

iii. Koje je mišljenje učenika o učinkovitosti nastave tehnologije i dizajna uz upotrebu kodiranja?

\section{Ograničenja}

i. Istraživanje je provedeno s učenicima sedmih razreda srednje škole Şehit Hüseyin Ruso u Sjevernom Cipru u školskoj godini 2016./2017.

ii. Nastavne aktivnosti u istraživanju odvijale su se uz pomoć osobnoga računala i interaktivne pametne ploče.

\section{Metoda}

\section{Dizajn istraživanja}

Ova studija dizajnirana je kao mješoviti model istraživanja, tj. korištene su obje kvantitativne i kvalitativne metode. Istraživanje je zasnovano na sekvencijalnom deskriptivnom modelu mješovitih metoda (Creswell, 2014). Stoga, učinak primijenjene nastave kodiranja u eksperimentalnoj skupini i učinak tradicionalne metode primijenjene u kontrolnoj skupini na učeničke vještine prostornoga mišljenja analiziran je primarno prikupljanjem kvantitativnih podataka, a zatim prikupljanjem kvalitativnih podataka. Predtest i posttest eksperimentalnoga uzorka u kontrolnoj skupini primijenjen je u kvantitativnoj dimenziji istraživanja. U eksperimentalnoj skupini primijenjena je nastava tehnologije i dizajna revidirana kodiranjem, dok je u kontrolnoj skupini primijenjena tradicionalna nastava tehnologije i dizajna. Obje skupine poučavao je istraživač. Ipak, nastavu u eksperimentalnoj skupini izvodio je i učitelj informatike. Istraživanje je trajalo osam tjedana. Učionička okolina opremljena je interaktivnom pametnom pločom, a svi su vanjski distraktori minimizirani koliko je to bilo moguće.

\section{Uzorak}

Istraživanje je uključivalo učenike sedmoga razreda srednje škole Şehit Hüseyin Ruso iz gradskog centra Nicosiae, u školskoj godini 2016./2017. Istraživanje je provedeno s učenicima sedmoga razreda koji su imali nisku razinu tjeskobe i prilagodili se na školski život. Svi su učenici u istraživanju sudjelovali dobrovoljno. Pri formiranju uzoraka naročito se pazilo da sudionici budu u istom razredu (7. razred) i sličnih akademskih postignuća. Podatci o socioekonomskom statusu i akademskom postignuću učenika sedmoga razreda dobiveni su od školske administracije. Učenici jednake razine akademskoga postignuća odabrani su za sudjelovanje u istraživanju u eksperimentalnoj ili kontrolnoj skupini metodom nasumičnoga uzorkovanja. Većina sudionika u svojim je domovima imala osobno računalo i pristup internetu. Obitelji sudionika u srednjem su platežnom razredu (više od minimalne place) ili u nižem (minimalna plaća). Učenici 
izrazito visokoga ili niskoga akademskog postignuća isključeni su iz uzorka. Svaka skupina obuhvaćala je 30 učenika. Rezultati t-testa za utvrđivanje jednakosti između eksperimentalne i kontrolne skupine nisu pokazali statistički značajnu razliku između vještine vizualno-prostornoga mišljenja učenika eksperimentalne i kontrolne skupine. Ovaj rezultat pokazao je kako se formirane skupine mogu prihvatiti kao ekvivalentne za rezultate mjerenja vizualno-prostornoga mišljenja u predtestu.

\section{Prikupljanje podataka}

Za dobivanje kvalitativnih podataka tijekom istraživanja korišten je predtest, posttest i test trajnosti vizualno-prostornoga mišljenja koji je osmislio istraživač, a za analizu podataka je upotrijebljen program SPSS 23. Nužne službene dozvole za provođenje istraživanja dalo je Ministarstvo državnoga obrazovanja. Osmišljena su 62 pitanja za test vizualno-prostornoga mišljenja. Pitanja su pregledali stručnjaci područja i tri lingvista, nakon čega su izdvojili 50 pitanja. 15 dana kasnije stručnjaci su ponovo evaluirali stavke te su istraživači formirali test prostornoga mišljenja. Na ovaj način provjerena je valjanost sadržaja istraživanja.

Spomenuti test vizualno-prostornoga mišljenja sastojao se od tri dijela: prvi dio sastoji se od 13 pitanja i nazvan je „Mentalna rotacija”, drugi dio naziva „Prostorna specifičnost i analiziranje"sadrži 12 pitanja naziva, treći dio je sadrži 25 pitanja i nazvan je „Percepcija dubine i mentalno dovršavanje”. Test je sadržavao pitanja višestrukih odgovora, "A-B-C-D", a za odgovor na svako pitanje sudionici su imali minutu vremena. Kako bi prikupili podatke, istraživači su proveli test u svakoj regiji posebno. Test je prethodno primijenjen na 163 učenika javnih srednjih škola Turske Republike Sjeverni Cipar sljedećim redom: u Nicosiai na 56 učenika, u Famagustai na 38 učenika, u Kyreniai na 37 učenika, u Iskeleu na 17 učenika i u Güzelyurtu na 15 učenika.

Izračuni težine i specifičnosti stavki provedeni su za testove postignuća i sposobnosti koji mjere znanja i vještine. Očekivana vrijednost težine stavke "p" je oko 0,50 . Ako ta vrijednost poraste na +1 , razina težine stavke pada; ako vrijednost padne na 0 , razina težine stavke se povećava (Büyüköztürk i sur., 2016). Specifičnost stavke otkriva razinu koja razlikuje pojedince prema mjerenom svojstvu i u rasponu je između +1 i -1. Ako vrijednost specifičnosti stavke padne na negativne vrijednosti, otkriva obrnutu mjeru stavke koja se potom treba isključiti iz testa (Büyüköztürk i sur., 2016). Ako su indeksi specifičnosti $>0,40$, stavka je vrlo dobra; ako su između 0,39 - 0,30, stavka je dobra; ako su između $0,20-0,29$, treba ih razviti; ako je indeks $>0,20$, stavku treba isključiti iz testa (Büyüköztürk i sur, 2016). 21 stavka definirana je kao lagana; 20 je srednje teških, 9 je definirano kao teško. $S$ obzirom na specifičnost indeksa stavki, 17 ih je definirano kao „dobro”, a 33 kao „vrlo dobro”. Prosječna izračunata težina testa je 0,55. Za dobivanje kvalitativnih podataka, $u$ istraživanju je primijenjen Obrazac intervjua o nastavi tehnologije i dizajna revidiranoj upotrebom kodiranja. Obrazac se sastoji od pitanja kojima se utvrđuje mišljenju učenika koji su učili uz upotrebu kodiranja o učinkovitosti nastave tehnologije i dizajna. Tijekom pripreme i sastavljanja kvalitativnih 
pitanja u obzir je uzeta primarna svrha istraživanja. Razmotrena su i mišljenja četiri stručnjaka polja te učinjen pregled relevantne literature. Prema spomenutoj reviziji literature i mišljenjima stručnjaka, ekstrahirana je skupina pitanja i dizajniran Obrazac intervjua. Obrazac je predstavljen šestorici stručnjaka. Njihova su mišljenja sakupljena putem evaluacijskoga obrasca koji je osmislio istraživač. Evaluacija stručnjaka rezultirala je finaliziranjem Obrasca u obliku četiri pitanja. Nakon ovoga procesa, prema mišljenjima stručnjaka, istraživač je proveo pilot-intervju kako bi validirao jasnoću pitanja i učinio potrebne ispravke. Na taj je način finaliziran Obrazac za intervju, uz povratne informacije stručnjaka i pilot-studiju.

Intervjui su provedeni u svibnju 2017. Pouzdanost analize sadržaja za kvalitativne podatke $u$ istraživanju osigurala su neovisno dva stručnjaka i to za procese kodiranja, kategorizacije i tematizacije. Dva kodera evaluirala su pouzdanost kodova i tema, uz međusobnu usporedbu kompatibilnosti, zbog ispitivanja valjanosti istraživanja, a kako bi se osiguralo da svi kodovi, teme i sadržaji budu ispravljeni. Na kraju procesa kodiranja istraživači su revidirali sve kodove i teme. Primijenjen je Obrazac intervjua o nastavi tehnologije i dizajna uz upotrebu kodiranja licem u lice, a pitanja iz intervjua, koji je trajao približno 30 minuta, postavljena su svim sudionicama istim redom. Intervju je sniman audiouređajem.

Teme i kodovi dobiveni iz kvalitativnih podataka podvrgnuti su analizi sadržaja uz upotrebu programa NVIVO 12. Sudionici su dobili kodove $\mathrm{K}_{1}, \mathrm{~K}_{2}(\ldots)$ kako bi njihov identitet bio povjerljiv, a istraživač je organizirao i tumačio podatke u vezi s temama i podtemama. U toj analizi neka su mišljenja učenika direktno citirana kako bi odrazila njihove poglede (Yıldırım i Şimşek, 2011).

Pouzdanost je osigurana tako što je istraživač analizirao i interpretirao sve podatke i pronašao zajedničke teme i kodove. Prvo su oba istraživača odvojeno kodirali podatke, a nakon toga su izračunati postotci podudarnosti između kodova na $82 \%$. Prema Şencan (2005) i Yıldırım i Şimşek (2011) ovaj postotak sličnosti smatra se dovoljnim za pouzdanost. Preko $70 \%$ sličnosti odražava pouzdanost studije. Raspravilo se o slaganjima i neslaganjima te su učinjene potrebne prilagodbe.

Testovi trajnosti primijenjeni su šest tjedana nakon završetka istraživanja. $U$ eksperimentalnim istraživanjima preporučuje se kontrolna studija (test trajnosti) nakon određenoga vremenskog perioda (Heppner i sur., 1999). Iako test trajnosti varira prema ciljevima i karakteristikama istraživanja, literatura navodi da ga je dovoljno primijeniti šest tjedana nakon istraživanja (Campell i Stanley, 1963; Brown i sur., 2008). Scratch program kodiranja korišten je $u$ istraživanju zbog toga što je besplatan, otvorenoga pristupa, na turskom jeziku i koristan za mnoge različite discipline.

\section{Istraživački postupci}

\section{Integracija kodiranja s nastavom tehnologije i dizajna i oblikovanje programa poučavanja}

1. Provedena je anketa o potrebama nastave tehnologije i dizajna među učenicima državnih škola koji su odabrani stratificiranim uzorkovanjem, širom Sjevernog Cipra. 
2. Ciljana postignuća programa utvrđena su prema stavkama koje su se pojavile u analizi, i te ciljane dobiti klasificirane su prema razini kognitivne domene.

3. Planovi i aktivnosti nastave tehnologije i dizajna, usmjerene na ciljane dobiti, pripremljene su uz suradnju stručnjaka (učitelji informatike i tehnologije i dizajna).

4. U poučavanju programa dizajniranoga prema ASSURE modelu, pripremljenoga za eksperimentalnu skupinu, korišten je pristup orijentiran na učenika. $U$ fazi dizajna prema ASSURE modelu analizirani su učenici te utvrđene njihove obrazovne potrebe, individualne osobine i razine spremnosti. Prema tome, određeni su ciljevi u skladu s obrazovnim potrebama učenika analiziranim u prvom koraku. Na primjer, objašnjavanje važnosti elementa linije u dizajnu; pisanje algoritama upotrebom linije i pretvaranje dvodimenzionalnih $\mathrm{u}$ trodimenzionalne oblike.

Odabrane su primjerene tehnike poučavanja i materijali u fazi odabira strategija, tehnologija, medija i materijala. Kao obrazovni alati korišteni su papiri, olovke, pametna ploča i prijenosno računalo. $U$ fazi upotrebe tehnologije, medija i materijala, oblikovana je okolina u kojoj će učenici upotrijebiti odgovarajuće materijale u učionici. Također, pripremljeni su tematski slajdovi. Učenici su upoznati s ciljevima i sadržajem poučavanja te su im objašnjene koristi ovakvoga procesa učenja.

Tijekom faze učeničkoga sudjelovanja, za učenike su pripremljeni panoi i projektni primjeri. Planiran je način učinkovitoga sudjelovanja učenika. Tijekom faze evaluacije i ponavljanja, učenici su koristili samoprocjenu. Nadalje, evaluirali su koristi nastave ocjenjujući aktivnosti u nastavi. Razina postignuća ciljeva utvrđena je prema stvorenim projektima i doživljenim procesima u nastavi. Neki primjeri su bili: napiši jednostavan algoritam, nacrtaj predmet iz različitih očišta uz pomoć kodiranja, koristi logičke varijable.

5. U kontrolnoj skupini, u kojoj je primijenjen tradicionalni program poučavanja, nije bilo intervencije. Na sve učenike je primijenjen Test mjerenja vizualno-prostornoga mišljenja - predtest, posttest i test trajnosti.

\section{Proces eksperimentalne studije (Primjena programa i proceduralni koraci)}

1. tjedan: Provedba predtesta vizualno-prostornoga mišljenja. Naglašavanje inovacije dizajna, procesa dizajniranja i važnosti linijskoga faktora dizajna.

2. tjedan: Učenici pišu jednostavne algoritme koristeći metodu papira i olovke te opisuju slijed algoritama; naglašavanje i objašnjavanje učenicima slijeda operacija u algoritmu; primjena primjera iz padajućeg izbornika pokret, kontrola i olovka u Scratch programu mijenjajući položaj likova različitim metodama, primijenjene su naredbe mjesta i smjera.

3. tjedan: Provedba zadatka korištenja linija koje preoblikuju dvodimenzionalne u trodimenzionalne predmete. Učenici razvijaju trodimenzionalne oblike i razne arhitektonske dizajne u računalnoj okolini uz korištenje Scratch programa. Opažanje veze s nastavom geometrije. Mijenjanje izgleda lika, okretanje lika i upotreba ifelse naredbe u Scrath programu. 
4. tjedan: Učenici opažaju izgled predmeta iz različitih kutova, rotiraju likove za određeni broj stupnjeva i primjenjuju pokrete unaprijed i unatrag. Cilj ove faze je omogućiti učenicima stvaranje ideja o pokretanju mehaničkih kreacija te povezivanje tih aktivnosti s matematikom i drugim predmetima. Navedeno je primijenjeno $\mathrm{u}$ području dodjeljivanja nasumične vrijednosti i logičko-matematičkih operacija.

5. tjedan: Učenici ispravno odabiru razine u odnosu na likove i crtaju slike prema njihovom izgledu iz različitih kutova gledanja. Cilj je ove faze pružiti učenicima prilike za stvaranje različitih kreacija u tim aplikacijama i povezati te aktivnosti s matematikom i drugim predmetima. Definirani su podatci, primijenjene varijable i uvjeti.

6. tjedan: Učenici stvaraju nove likove i dizajniraju elemente u programu Scratch te sa stvorenim likovima stvaraju animacije. Učenici stvaraju i predstavljaju nove ideje za olakšavanje života hendikepiranih ili starijih ljudi te djece. Navedene aktivnosti povezuju se s Geometrijom, Likovnim i Prirodom. Eksperimentalna skupina učenika izvodila je projekte koristeći logičke varijable, okretanje likova, ifelse naredbe, nasumičnu dodjelu vrijednosti i naredbe smjera iz Scrath programa.

7. tjedan: Učenici dizajniraju likove kako bi promijenili izgled predmeta izbliza i izdaleka. Stavljaju te likove u različite pozicije i omogućuju pokrete korištenjem efekata; pripremaju oglas proizvoda koji su razvili. Ove aktivnosti povezane su s Geometrijom, Matematikom, likovnim i prirodnim predmetima. Učenici evaluiraju projekt.

8. tjedan: Učenici dizajniraju produkt primjeren njihovim željama i potrebama. Pripremanje tih proizvoda odvija se u obliku animacije u Scratch programu. U finalnoj fazi ovoga tjedna učenici međusobno ocjenjuju svoje originalne proizvode.

\section{Statistička analiza}

Podatci dobiveni predtestom, posttestom i testom trajnosti pokazuju normalnu distribuciju prema Tabachnick i Fidellu (2013). Stoga, analizu treba provesti parametrijskim testovima. Analiza kvantitativnih podataka provedena je t-testom i dvosmjernom analizom varijance za složene mjere, pri čemu je vrijednost $\mathrm{p}<0,05$ smatrana statistički značajnom. Kvalitativni podatci podvrgnuti su analizi sadržaja te su utvrđeni teme i kodovi. Zbog upotrebe parametrijskih testova u istraživanju također se ispitalo zadovoljavaju li podatci pretpostavke normalnosti, nedostajućih vrijednosti $(-)$, ekstremnih vrijednosti (-), multikolinearnost i varijancu homogenosti. Pri obradi rezultata regresijske analize i testa vizualno-prostornoga mišljenja, VIF vrijednosti bile su u rasponu od 1,00 do 1,025, CI vrijednosti bile su između 1 i 9,159, a vrijednosti tolerancije bile su prilično visoke, u rasponu između 1,00 i .976. Primijećeno je da su pretpostavke multikolinearnosti zadovoljene te se u vezi s njima nije naišlo na problem.

\section{Rezultati}

U istraživanju su upotrijebljeni kvantitativna statistika i kvalitativni intervjui kako bi se utvrdila razina učinkovitosti primijenjenoga programa revidiranoga upotrebom kodiranja u nastavi tehnologije i dizajna na vještine vizualno-prostornoga mišljenja učenika. 


\section{Prvo istraživačko pitanje}

U prvom podproblemu studije istraživano je postojanje statistički značajne razlike između rezultata predtesta vizualno-prostornoga mišljenja između eksperimentalne i kontrolne skupine. Prvo je testirana normalnost distribucije s Kolmogorov-Smirnov testom. Shapiro-Wilk preporuča se u slučajevima kada je broj opservacija manji od 30, a Kolmogorov-Smirnov kada je taj broj veći od 30 (Can, 2014).

Tablica 1.

Kao što je vidljivo iz Tablice 1, nisu pronađene statistički značajne razlike između distribucija promatranih mjera. Sve mjere, oboje u eksperimentalnoj i kontrolnoj skupini, normalno su distribuirane $(\mathrm{p}>.05)$. Normalna distribucija podataka za obje skupine također je evaluirana mjerom asimetričnosti [predtest (E/C): .654/.792; posttest (E/C): .131/.419; test trajnosti (E/C): .247/.444] i spljoštenosti [predtest (E/C): .049/.592; posttest (E/C): -.389/-.282; test trajnosti (E/C): -1.02/-.105], histogramima, dijagramom raspršenosti (distribucije su raspršene u obliku elipse) i Q-Q grafom distribucije. Mjere asimetrije i spljoštenosti su u rasponu između +1.5 i -1.5. Preporuka je da se sve spomenute metode evaluiraju zajedno s pretpostavkom normalne distribucije (McKillup, 2012; Stevens, 2009; Tabachnick i Fidel, 2013). Prema toj preporuci zaključili smo da su normalnost distribucije i koeficijenti varijabilnosti podataka u prihvatljivom rasponu.

Kako bi se upotrijebili parametrijski testovi, potrebno je ispitati homogenost varijance (Büyüköztürk i sur., 2016). Levene test (vidi Tablicu 4) upotrijebljen je kako bi se ispitala homogenost varijance i rezultati predtesta, posttesta i testa trajnosti eksperimentalne $\mathrm{i}$ kontrolne skupine. Utvrđeno je da je pretpostavka homogenosti varijance zadovoljena te da moguće primijeniti parametrijske testove.

Primijenjen je t-test za nezavisne uzorke. Iz Tablice 2 vidljiva je značajna razlika između rezultata predtesta vizualno-prostornoga mišljenja između eksperimentalne i kontrolne skupine u nastavi tehnologije i dizajna.

Tablica 2.

Kako se vidi iz Tablice 2, nema značajne razlike između eksperimentalne $(\chi=20,03)$ $\mathrm{i}$ kontrolne skupine $(\chi=20,76) \mathrm{u}$ predtestu vizualno-prostornoga mišljenja $\left(\mathrm{t}_{(58)} .427\right.$, $\mathrm{p}>, 05)$. U vezi s tim može se ustvrditi da su vještine vizualno-prostornoga mišljenja učenika iz eksperimentalne i kontrolne skupine bile na istoj razini. Prema pōdatcima iz Tablice 2, može se zaključiti da su obje eksperimentalna i kontrolna skupina imale jednake rezultate testa vizualno-prostornoga mišljenja, što daje odgovor na prvo istraživačko pitanje.

$\mathrm{U}$ istraživanju je potrebno ispitati je li zadovoljena pretpostavka sferičnosti kako bi se primijenila analiza varijance za ponovljene mjere. Iz tog razloga primijenjen je Mauchlyev test sferičnosti (Gamst i sur., 2008). U slučajevima u kojima pretpostavka sferičnosti ne može biti zadovoljena, analiza varijance rezultata provodi se GreenhouseGeiserovom ispravkom (Tabachnick i Fidell, 2013). 
Tablica 3.

Pri ispitivanju rezultata dobivenih ponovnim mjerenjem vizualno-prostornoga mišljenja, vidljivo je kako se pretpostavka sferičnosti ne može potvrditi ( $\mathrm{W}=, 858$, $\mathrm{p}<, 05)$. Prema tome, Greenhouse-Geisser ispravka uzeta je u obzir pri ispitivanju učinka mjerenja unutar skupine. Greenhouse Geisser F omjer prikazan je u Tablici 3.

Kako bi se upotrijebili parametrijski testovi, potrebno je ispitati homogenost varijance (Büyüköztürk i sur., 2016). Levenov test primijenjenje za ispitivanje varijance homogenosti rezultata dobivenih predtestom, posttestom i testom trajnosti eksperimentalne i kontrolne skupine. Rezultati Levenova testa prikazani su u Tablici 4.

Tablica 4.

Iz Tablice 4 vidljivo je kako nema značajne razlike između varijanci u obje skupine prije eksperimentalnoga postupka. Drugim riječima, varijance eksperimentalne i kontrolne skupine su homogene za sve zavisne varijable prema mjerama predtesta $(\mathrm{F}=, 000, \mathrm{p}>, 05)$. Prema dobivenim podatcima mjera posttesta, potvrđeno je postignuće homogenosti varijance $(\mathrm{F}=, 00, \mathrm{p}>, 05)$. Prema rezultatima mjere testa trajnosti, također je potvrđena homogenost varijanci $(\mathrm{F}=, 128, \mathrm{p}>, 05)$.

$\mathrm{U}$ istraživanju je primijenjen Boxov $\mathrm{M}$ test kako bi se testirala jednakost matrica kovarijance zavisnih varijabli. Rezultati Boxova $\mathrm{M}$ testa također su prikazani u Tablici ispod.

Tablica 5.

Prema podatcima iz Tablice 5 (Boxov $M=10,805$ ), vidljivo je da je pretpostavka višestrukih normalnosti zadovoljena za vještine vizualno-prostornoga mišljenja. Razmatrajući ukupne evaluacije podataka, sve su pretpostavke nužne za primjenu dvosmjerne analize varijance zadovoljene.

\section{Drugo istraživačko pitanje}

U kontekstu drugog istraživačkoga pitanja utvrđivalo se postojanje statistički značajne razlike između rezultata posttesta i testa trajnosti eksperimentalne i kontrolne skupine. Vrijednosti aritmetičke sredine i standardne devijacije rezultata eksperimentalne i kontrolne skupine na predtestu, posttestu i testu trajnosti vizualno-prostornoga mišljenja prikazane su u Tablici 6.

Tablica 6.

Prema rezultatima testa vizualno-prostornoga mišljenja eksperimentalne skupine, izračunata aritmetička sredina rezultata predtesta je $\bar{\chi}=20,03$, aritmetička sredina posttesta je $\bar{\chi}=26,90$ i aritmetička sredina rezultata testa trajnosti je $\bar{\chi}=29,63$. Aritmetička sredina rezultata predtesta kontrolne skupine iznosi $\bar{\chi}=20,76$, aritmetička sredina posttesta je $\bar{\chi}=22,40$ i aritmetička sredina testa trajnosti iznosi $\bar{\chi}=21,60$.

U svjetlu ovih rezultata, dvofaktorska analiza varijance primijenjena je za ponovljene mjere kako bi se utvrdilo postojanje bilo kakve promjene u usporedbi s rezultatima 
predtesta, posttesta i testa trajnosti eksperimentalne i kontrolne skupine. Rezultati su prikazani u Tablici 7.

\section{Tablica 7.}

Prema analizi varijance iz Tablice 7, utvrđena je statistički značajna razlika između ukupne vrijednosti testa trajnosti, posttesta i predtesta eksperimentalne skupine i ukupne vrijednosti rezultata testa trajnosti, posttesta i predtesta kontrolne skupine. Drugim riječima, grupni efekt je značajan $\left[\mathrm{F}_{(1-58)}=5,12, \mathrm{p}<, 05\right]$. Na osnovi ovoga rezultata može se reći da postoji statistički značajna razlika između srednjih rezultata na skali vizualno-prostornoga mišljenja, bez razlike između predtesta, posttesta i testa trajnosti eksperimentalne i kontrolne skupine.

Iz Tablice 7 vidljivo je da je razlika između srednjih rezultata predtesta, posttesta i testa trajnosti svih sudionika u eksperimentalnoj i kontrolnoj skupini, bez razlikovanja skupina, značajna $\left[\mathrm{F}_{(2-116)}=19,48, \mathrm{p}<, 05\right]$. U tom kontekstu, može se reći da se razine (vještine) vizualno-prostornoga mišljenja sudionika mijenjaju ovisno o eksperimentalnom procesu kada se ne radi grupna diskriminacija. Nadalje, rezultat zajedničkoga učinka, kritičnog za ovu studiju (grupno mjerenje), je značajan $\left[\mathrm{F}_{(2-116)}=12,30, \mathrm{p}<, 05\right]$.

Prema rezultatima dobivenim analizom varijance, primijenjen je Bonferroni test, kao jedan od posthoc testova, na rezultate predtesta, posttesta i testa trajnosti svih sudionika, kako bi se utvrdila značajnost razlike između skupina. Bonferroni test pokazuje razliku između skupina i razinu značajnosti te razlike, slobodnu od pogrešaka prvog i drugog tipa (Miller, 1969). Rezultati su prikazani u Tablici 8.

\section{Tablica 8.}

Prema Bonaferroni testu usporedbe u Tablici 8, razlika između aritmetičkih sredina vizualno-prostornoga mišljenja u predtestu $(\bar{\chi}=20,03)$ i posttestu $(\bar{\chi}=26,90) \mathrm{u}$ eksperimentalnoj skupini je značajna $\left(-6.867^{*}, \mathrm{p}<, 05\right)$. Slično tomu, razlika između aritmetičkih sredina predtesta $(\bar{\chi}=20,03)$ i testa trajnosti $(\bar{\chi}=29,63)$ eksperimentalne skupine je značajna $\left(-9.600^{*}, \mathrm{p}<, 05\right)$. Nije utvrđena značajna razlika između aritmetičkih sredina rezultata posttesta $(\bar{\chi}=26,90)$ i testa trajnosti $(\bar{\chi}=29,63)$ eksperimentalne skupine $(2,73, \mathrm{p}>, 05)$.

Razlike između aritmetičke sredine rezultata predtesta $(\bar{\chi}=20,76)$ i posttesta $(\bar{\chi}=22,40)$ vizualno-prostornoga mišljenja primijenjenoga u kontrolnoj skupini nije značajna $(-1.633, \mathrm{p}>, 05)$. Slično tomu, razlika između aritmetičke sredine predtesta $(\bar{\chi}=20,76)$ i testa trajnosti $(\bar{\chi}=21,60)$ kontrolne skupine nije značajna $(-, 83, \mathrm{p}>, 05)$. Nije pronađena značajna razlika između aritmetičke sredine rezultata posttesta $(\bar{\chi}=22,40)$ i testa trajnosti $(\bar{\chi}=21,60)$ kontrolne skupine $(, 800, \mathrm{p}>, 05)$.

Grafički rezultat predtesta, posttesta i testa trajnosti primijenjenih u eksperimentalnoj (skupina 1) i kontrolnoj (skupina 2) skupini prikazani su u Grafikonu $1 \mathrm{u}$ integriranom obliku. Vidljivo je da su eksperimentalna i kontrolna skupina jednake u rezultatima pred-testa (mjera 1), što znači da su bile jednake u početku istraživanja. Razlika između 
rezultata posttesta skupina (mjera 2) pokazuje značajan porast u korist eksperimentalne skupine. Razlika između testa trajnosti eksperimentalne i kontrolne skupine je visoka, kao što se vidi iz Grafikona (mjera 3). Za ustanovljenu razliku između rezultata posttesta i testa trajnosti u korist eksperimentalne skupine može se utvrditi da revidirani program predmeta tehnologija i dizajn uz upotrebu kodiranja ima značajan učinak na vještine vizualno-prostornoga mišljenja učenika.

\section{Grafikon 1.}

\section{Treće istraživačko pitanje}

Mišljenja učenika koji su poučavani kodiranjem o učinkovitosti nastave tehnologije i dizajna smješteni su u kvalitativnu dimenziju istraživanja glavnih tema - kognitivna, afektivna, vještine i vanjska - a uz njih su vezane i kodirane podteme.

Grafikon 2.

Iz Grafikona 2 vidljivo je da su učenici evaluirali učinkovitost nastave vezano uz četiri glavne teme. Mišljenja učenika vezana uz kognitivne ishode usredotočena su na primjenu, razmišljanje, evaluaciju, analizu i trajnost. Može se zaključiti, budući da su te podteme znane kao kognitivni ishodi visoke razine, da postoje pozitivni učinci procesa učenja na vizualno-prostorne vještine. Nadalje, vidljivo je da kognitivni procesi znanja i percepcije relativno visoke razine imaju pozitivan odraz na trajnost učenja. Mišljenja učenika koji su poučavani kodiranjem vezana uz kognitivne ishode su sljedeća:

Nakon kodiranja, mogu naći rješenje bilo kojeg problema. Ako je nešto potrgano, razmišljamo kako bismo to popravili $\left[\mathrm{K}_{11}\right]$. Kodiranje ima pozitivan učinak na moje dizajne; znamo crtati trodimenzionalne oblike $\left[\mathrm{K}_{17}\right]$. Nastava je izvođena praktično. Nešto ostaje u našem umu $\left[\mathrm{K}_{23}\right]$. Znam dizajnirati nove produkte. Mogao sam se sjetiti tema koje smo naučili na prošlim satima $\left[\mathrm{K}_{6}\right]$. Nisam razumjela što crtaju prije praktične nastave. Crtali su neke čudne stvari i nisam razumjela koje. Ipak, nakon što sam počela upotrebljavati ovaj program, sve se promijenilo $\left[\mathrm{K}_{5}\right]$. Počeo sam sve percipirati $\left[\mathrm{K}_{18}\right]$. Razumijem veličinu predmeta kada ih gledam. Čak ja mogu nacrtati jednostavne arhitekturalne nacrte $\left[\mathrm{K}_{3}\right]$. Lako mogu razumjeti matematičke probleme $\left[\mathrm{K}_{16}\right]$. Prije sam imao problema u nastavi matematike, ali nakon učenja Scratcha sve se čini lakše $\left[\mathrm{K}_{21}\right]$. Kodiranje ima pozitivan učinak na geometriju u nastavi Matematike, na vulkane i molekule u nastavi Prirode, crtanje karata na nastavi društvenih znanosti $\left[\mathrm{K}_{18}\right]$.

Tri su podteme smještene u afektivne ishode učenika koji su poučavani kodiranjem: stav, motivacija i svijet mašte. Može se reći da su učenici koji su prošli poučavanje kodiranja pokazali pozitivne stavove o maštanju, dizajniranju vizualno-prostornih elemenata i korištenju predmeta s njihovim vizualno-prostornim aspektima. Navodi se kako je nastava tehnologije i dizajna koja je uključivala kodiranje olakšala percipiranje i materijaliziranje objekata i njihovih vizualno-prostornih dimenzija. Istraživanje je otkrilo da je Scratch program učinkovit u području mašte i razvijanja novih ideja. Iz mišljenja učenika također proizlazi kako je razumljivo da se nastava koja sadrži 
kodiranje pozitivno odražava na trajnost i razumljivost kognitivnih ishoda i motivira učenike. Primijetili su da je proces učenja postao zaigran i zabavan zbog kodiranja. Štoviše, značajne su promjene učeničkih stavova. Mišljenja učenika koji su bili uključeni u nastavu kodiranjem o afektivnim ishodima su sljedeća:

Pri upotrebi kodiranja u poučavanju dizajna, pojavile su se kreativne i nove ideje $\left[\mathrm{K}_{13}\right]$. Scratch program doveo je do razvoja moje mašte $\left[\mathrm{K}_{4}\right]$. Aktivnost koja mi se najviše svidjela na nastavi je stvaranje likova i zamišljanje $\left[K_{27}\right]$. 3-D crteži šire našu maštu $\left[\mathrm{K}_{25}\right]$. U matematici, možemo razlikovati dužinu-dubinu oblika $\left[\mathrm{K}_{1}\right]$. Sve kodiranje i projekti doveli su do toga da zavolim predmet $\left[\mathrm{K}_{11}\right]$. Kodiranje je nužno $\left[\mathrm{K}_{16}\right]$. Nastava kodiranjem je bila ugodna $\left[\mathrm{K}_{28}\right]$. Poučavanje kodiranja je potrebno $\left[\mathrm{K}_{1}\right]$. Osjećao bih se nepotpuno da me nisu podučavali kodiranju $\left[\mathrm{K}_{10}\right]$. Likovi su bili tako slatki, pokretali smo ih kako smo htjeli $\left[\mathrm{K}_{9}\right]$. Likovima smo dodijelili uloge i to je bilo zabavno $\left[\mathrm{K}_{19}\right]$. Jako smo se zabavili $\left[\mathrm{K}_{16}\right]$. Naša se mašta razvila $\left[\mathrm{K}_{11}\right]$. Kreativno mišljenje razvija našu maštu $\left[\mathrm{K}_{23}\right]$. Na drugim satima obično ostajemo unutar granica jer imamo pravila $\left[\mathrm{K}_{27}\right]$.

Tri su podteme smještene u glavnoj temi vještine: prostorne, psihomotorne i društvene vještine. Osim pozitivnih učinaka na kognitivne i afektivne stavove učenika, upotreba kodiranja pozitivno je utjecala na vještine razlikovanja, oblikovanja i slaganja vizualnoprostornih objekata učenika. Mišljenja učenika naglašavaju trodimenzionalno mišljenje, percipiranje objekta sa svim dimenzijama i crtanje u digitalnoj okolini, stvaranje originalnih dizajna, prijenos poboljšanih prostornih vještina u područje matematike, likovnog i drugih predmeta. Učenici su naveli da su njihove prostorne vještine razvijene i izrazili važnost prakse kodiranja, mišljenja, logičkoga razmišljanja i motiviranosti. Također su naveli da rad s računalima i kodiranje imaju poseban doprinos u poboljšanju vještina planiranja dizajna, razvijanja projekata i timskoga rada. Mišljenja učenika koji su poučavani kodiranjem vezana za ishode $s$ obzirom na vještine su sljedeća:

Naučio sam crtati trodimenzionalne oblike. Preferiram trodimenzionalne vizije prilikom dizajniranja. $\mathrm{U}$ dvodimenzionalnom obliku vidimo samo prednji dio $\left[\mathrm{K}_{17}\right]$. Možemo vidjeti bočne i stražnju stranu predmeta u trodimenzionalnim prikazima $\left[\mathrm{K}_{14}\right]$. Kodiranje pruža obogaćenu okolinu $\left[\mathrm{K}_{11}\right]$. Prije nisam znala crtati trodimenzionalne oblike. Sada pak znam nacrtati auto, autobus ili neformirane objekte uz geometrijske $\left[\mathrm{K}_{16}\right]$. Ono što smo naučili $\mathrm{u}$ ovom obliku nastave s kodiranjem pomoglo nam je $\mathrm{u}$ drugim predmetima $\left[\mathrm{K}_{28}\right]$.Znamo razlikovati dubinu, dužinu i visinu oblika na nastavi matematike. Zajedno s prijateljima znamo razlikovati likove i pozadinu $\left[\mathrm{K}_{1}\right]$. Kombinirao sam linije pri stvaranju likova i prizora. Više mi se sviđaju trodimenzionalni oblici od dvodimenzionalnih; trodimenzionalni oblici predstavljaju razvijenu maštu $\left[\mathrm{K}_{23}\right]$. Jako mi se sviđaju trodimenzionalni uzorci. Prije nastave tehnologije i dizajna nisam znao crtati trodimenzionalne oblike. Nakon što sam sudjelovao u nastavi, crtam mnogo bolje oblike $\left[\mathrm{K}_{5}\right]$.Znam preoblikovati kvadrat, trokut, ovoid i pravokutnik u trodimenzionalni oblik, čak bilo koju dvodimenzionalnu figuru u trodimenzionalnu $\left[\mathrm{K}_{3}\right]$. Znam nacrtati trodimenzionalni ocean i more na satu društvenih znanosti $\left[\mathrm{K}_{9}\right]$. Ako napravimo model stola, ne možemo to napraviti kako smo zamislili, ali s trodimenzionalnim 
kodiranjem koje smo naučili, možemo $\left[\mathrm{K}_{1}\right]$. Animacije su prezabavne $\left[\mathrm{K}_{29}\right]$. Nastava kodiranja bila je jako zabavna. Radili smo prekrasne stvari $\left[\mathrm{K}_{16}\right]$.

Četiri su podteme smještene u glavnu temu vanjski: prijenos, profesionalna orijentacija i štednja. Primijećeno je da su učenici koji su učili kodiranjem motivirani za prijenos znanja i informacija iz nastave u svakodnevni život i druge predmete. Može se reći da su stvoreni vizualni produkti kodiranjem koje je služilo kao pokretačka sila za osnaživanje oboje učenja i dizajniranja novih tvorbi, jer su ga učenici doživjeli kao zabavno i ugodno. Također je nađeno da je podučavanje kodiranjem promijenilo profesionalnu orijentaciju učenika. Štoviše, učenici su izjavili da su te vrste praksi dostupne. Mišljenja učenika koji su sudjelovali u nastavi kodiranja vezana za vanjske ishode su sljedeća:

Ono što sam naučio na nastavi tehnologije i dizajna mogu koristiti u nastavi Geometrije $\left[\mathrm{K}_{1}\right]$. Postoji kocka u toj nastavi. To znanje mogu koristiti u Matematici, Prirodi i drugim predmetima $\left[\mathrm{K}_{10}\right]$. Ono što sam naučila u kodiranju mogu prenijeti $u$ svoj svakodnevni život $\left[\mathrm{K}_{12}\right]$. Naša vještina istraživanja se razvila $\left[\mathrm{K}_{17}\right]$. Kodiranje ima učinak na izbor profesije u budućnosti $\left[\mathrm{K}_{24}\right]$. Kodiranje ima mnoge privilegije $\left[\mathrm{K}_{11}\right]$. Može pomoći u svakoj profesiji $\left[\mathrm{K}_{18}\right]$. S kodiranjem možeš napraviti neograničen broj kreacija $\left[\mathrm{K}_{26}\right]$. Korištenje kodiranja u nastavi tehnologije i dizajna ima veliki doprinos. Na primjer, promijenio se moj izbor profesije $\left[\mathrm{K}_{3}\right]$. Stvaranje projekta mnogo je bolje od kupovanja materijala, stoga, ima aspekte štednje i također štedi vrijeme. Ne gubimo vrijeme i možemo popraviti moguće greške $\left[\mathrm{K}_{29}\right]$. Ne možemo izgraditi model ako je potrgan, čak i ako ga ponovo napravimo, to bi puno koštalo $\left[\mathrm{K}_{13}\right]$. Kodiranje možemo koristiti za konstrukciju robota. Tako možemo pokretati robota $\left[\mathrm{K}_{14}\right]$. Možemo dijeliti projekte na internetu te poticati se međusobno i našu okolinu na izradu projekata $\left[\mathrm{K}_{24}\right]$.

\section{Rasprava}

Ovo istraživanje ispitivalo je učinke kodiranja upotrebom Scrath programskoga jezika na vještine vizualno-prostornoga mišljenja učenika u nastavi tehnologije i dizajna. S obzirom na cilj istraživanja, rezultati testa vizualno-prostornoga mišljenja koji se sastojao od tri dijela - misaona rotacija, prostorna specifičnost i analiza, percepcija dubine i misaono dovršavanje - su poboljšani. Učinkovitost i trajnost tradicionalne nastave tehnologije i dizajna i inovativna nastava tehnologija i dizajna uz upotrebu kodiranja testirane su u eksperimentalnom modelu istraživanja. Ustanovljeno je da su rezultati posttesta i testa trajnosti vizualno-prostornoga mišljenja učenika iz eksperimentalne skupine značajno različiti od onih učenika u kontrolnoj skupini u nastavi tehnologije i dizajna. Prema ovom rezultatu, može se tvrditi da je program nastave tehnologije i dizajna revidiran programom kodiranja Scratch bio učinkovit u poboljšanju vizualno-prostornoga mišljenja učenika eksperimentalne skupine u dimenzijama mentalne rotacije, percepcije dubine, prostorne specifičnosti i analize. Ovi rezultati pokazuju sličnost $\mathrm{s}$ rezultatima ostalih istraživanja u literaturi: $\mathrm{u}$ istraživanju sa srednjoškolskim učenicima Dere (2017) je utvrdio značajne razlike u korist učenika iz 
eksperimentalne skupine $\mathrm{u}$ vještinama prostorne vizualizacije, zamišljanja presijecanja površina predmeta i vještini mentalne rotacije oblika. Septia i sur. (2018) ustanovili su da je njihova interaktivna nastava u području multimedija bila učinkovita s obzirom na sposobnosti mentalne rotacije, prostorne orijentacije i prostorne vizualizacije. $U$ još jednom istraživanju, zaključeno je da su aktivnosti zasnovane na geometrijskim i mehaničkim igrama bile učinkovite u poboljšavanju vještina prostornoga mišljenja učenika srednje škole (Demirkaya i Masal, 2017). Jones i Burnett (2008) otkrili su korelaciju između sposobnosti mentalne rotacije i računalnoga programiranja. Heng i sur. (2014) osmislili su prostornu igru kako bi poboljšali učeničku prostornu orijentaciju i pamćenje te ustanovili kako je ta igra učinkovita metoda razvijanja navedenih sposobnosti u kratkom periodu. Çalışkan (2016) koji je primijenio test mentalne rotacije na eksperimentalnom uzorku, otkrio je da upotreba dinamične programske podrške u procesu poučavanja geometrijskih tijela u kurikulu Matematike podržava iskustva učenja i prostorno mišljenje učenika. Učenici u ovom istraživanju izjavili su da je kurikul revidiran kodiranjem imao pozitivan učinak na prostorne sadržaje poput zamišljanja objekata, percepcije dubine i rasuđivanja. Također, novi kurikul zasnovan na kodiranju, fokusiran na učenike i različit od tradicionalnih obrazovnih pristupa, doživljen je kao zabavan, ugodan i razvojni proces. Nadalje, mnoge studije pokazale su kako kodiranje i/ili računalno programiranje imaju pozitivne učinke na učenje učenika. Ustanovljeno je da učenici percipiraju računalno programiranje kao ugodnu i privlačnu aktivnost učenja (Fessakis i sur. 2013; Liao i Bright, 1991). Štoviše, Fessakis i sur. (2013) otkrili su da se učeničke matematičke vještine, komunikacijske vještine i suradničke vještine razvijaju u okružju računalnoga programiranja Logo. Učenici koji su bili motivirani i imali pozitivne stavove prema predmetu bili su aktivniji u stvaranju novih ideja, usavršavanju projekata i produbljivanju mašte. U kvalitativnoj dimenziji ovoga istraživanja otkriveno je da su učenici iz eksperimentalne skupine imali pozitivne stavove prema predmetu i veću motivaciju. Rezultati posttesta, testa trajnosti i motivacija učenika iz eksperimentalne skupine bili su viši nego oni učenika iz kontrolne skupine, što je rezultat funkcionalnosti novoga programa zasnovanoga na kodiranju. Stoga, predloženi kurikul u ovom istraživanju može se ocijeniti kao primjenjiv i održiv. Sličnu studiju proveo je Kalay (2015) s učenicima sedmoga razreda. Obrazovno okruženje bilo je obogaćeno dinamičnim geometrijskim programom Cabri 3D. Rezultati su pokazali kako spomenuto ozračje stvara značajnu razliku u vještinama prostorne orijentacije učenika eksperimentalne skupine. Nadalje, ustanovljeno je da su učenici imali pozitivne stavove usmjerene na računalno-podržano okruženje. U istraživanju Howland i Gooda (2015) utvrđeno je da su učenici bili vrlo motivirani za stvaranje vlastitih igara u Flip programu, grafičkom programskom jeziku. Većina učenika znali su napisati mali program koji je bio katalizator interaktivnih ponašanja. Topaloğlu (2011) je proveo istraživanje vizualnih vještina učenika sekundarnoga obrazovanja. Utvrđen je značajan porast prostornoga mišljenja učenika prilikom upotrebe Cabri 3D programa. Učenici iz eksperimentalne skupine stvarali su vlastite projekte i prezentirali maštovite 
kreacije uz upotrebu računalno potpomognutih animacija. Otkriveno je da su vizualno potpomognute aktivnosti učenja imale pozitivne učinke na trajnost učenja. Studija Gunaya (2015) otkrila je značajan odnos između sposobnosti prostornoga mišljenja i animacije. Ovi su rezultati sukladni $s$ učeničkim mišljenjima o korištenju prostornih vještina, primjeni i prijenosu tema u kvalitativnoj dimenziji našega istraživanja. Istraživanje Francis i sur. (2016) polučilo je rezultate koji podržavaju tvrdnju kako učenje kroz aktivnost i stvarni život ima pozitivnije učinke na prostorno mišljenje od tehnike predavanje-slušanje. Signali rukama učenika tijekom procesa programiranja pokazali su poboljšanje njihove sposobnosti prostornoga mišljenja na unaprijeđenoj i složenoj razini, putem njihovih obrazovnih iskustava. Ti zaključci sukladni su s mišljenjima učenika iskazanima u temama primjene, upotrebe prostornih vještina i psihomotornih vještina u kvalitativnoj dimenziji našega istraživanja. Nadalje, rezultati istraživanja Saltan i Kara (2016) o razvojnoj značajki programa Scratch u odnosu na vizualizaciju i računalno mišljenje u skladu su s mišljenjem učenika o programu Scratch. Ada (2016) je u svom istraživanju utvrdio da je program učenja zasnovan na mentalnim aktivnostima poboljšao prostorne vještine sudionika.

Druga dimenzija koja se pojavila u kvalitativnoj dimenziji istraživanja bila je učinkovitost nastave tehnologije i dizajna revidirane kodiranjem s obzirom na kognitivne kompetencije visoke razine poput analize, sinteze i evaluacije, izražene u Bloomovoj taksonomiji. Učenici su izjavili da su stekli pozitivna iskustva učenja u području razmišljanja, povezivanja vizualno-prostornih stavki, razlikovanja sličnih i različitih stavki, zamišljanja dubine i dimenzija. Navedeno se smatra važnim za prijenos znanja i učenja u svakodnevni život. Otkriveno je kako obogaćena iskustva učenja i poučavanja učenika programskom podrškom značajno poboljšavaju prostorne vještine učenika u istraživanju Özlü (2014). Akbay (2015) je utvrdio da se postignuće prostorne vizualizacije u eksperimentalnoj skupini poboljšalo u njegovoj studiji provedenoj u okruženju igre Minecraft. Na sličan su način u našem istraživanju, u kojem smo upotrijebili program Scratch, ustanovljeni njegovi pozitivni učinci na rezultate posttesta i testa trajnosti dimenzija prostornih vještina poput mentalnoga rotiranja, percepcije dubine i mentalnoga dovršavanja te na stavove učenika o primjeni. U kvalitativnoj dimenziji istraživanja učenici su naveli porast razumijevanja u području Matematike i Geometrije te su poželjeli imati slična iskustva učenja podržana kodiranjem u drugim predmetima. Neki učenici naveli su da su primijenili Scratch u nastavi Prirode i Engleskog jezika. Smatrali su važnim prenijeti iskustva učenja iz nastave tehnologije i dizajna podržane kodiranjem na druge predmete. Gül (2014), Gül i Karataş (2015), Batdal Karaduman (2012) i Kök (2012) svi su na sličan način utvrdili pozitivan odnos između prostornih sposobnosti i razumijevanja geometrije. Rezultati tih istraživanja sukladni su mišljenjima učenika o prostornim sposobnostima i prijenosu tema izraženim u kvalitativnoj dimenziji ovoga istraživanja. $S$ druge strane, većina provedenih istraživanja prostornih vještina fokusirala se na područje matematike, geometrije i informatike. Ipak, mnogo je različitih disciplina, poput tehnologije i dizajna, u kojima se intenzivno 
koriste prostorne vještine. Bez obzira na ovu činjenicu čini se kako su istraživanja nastave tehnologije i dizajna ograničena. Jedno od rijetkih istraživanja ove teme proveli su Charcharos i sur. (2015) u kojemu je razvijen test prostornoga mišljenja u području geografije. Nadalje, u tradicionalnom modelu poučavanja učenje se događa na razini znanja i razumijevanja. S druge strane, postoje dokazi da je učenje usredotočeno na učenika, zasnovano na projektu i učenju u praksi, fokusirano na vještine, poduzetništvo i inovaciju. U ovom kontekstu utvrđeno je da će kodiranje kao jedan od digitalnih alata s inovativnim sučeljem biti među prioritetima naprednih obrazovnih sustava $\mathrm{u}$ učenju učenika i oblikovanju budućnosti (OECD, 2017).

Rezultati istraživanja u literaturi pokazuju da eksperimentalne primjene imaju veći učinak na učenje učenika. Ovo istraživanje pokazalo je pozitivan učinak poučavanja kodiranjem uz upotrebu Scratch programa u nastavi tehnologije i dizajna na vizualnoprostorne vještine učenika iz eksperimentalne skupine. Kvalitativni rezultati istraživanja također su pokazali da podučavanje kodiranjem pozitivno djeluje na učenje učenika. Prema mišljenjima učenika, poučavanje uz upotrebu kodiranja je podržalo njihovo učenje, povećalo motivaciju i poboljšalo njihovu sposobnost vizualno-prostornoga mišljenja. Ovaj rezultat zahtijeva da se predmetu poput Tehnologije i dizajna, s očitom inovativnom dimenzijom, pristupi na multidimenzionalan način. Budući da će algoritamska programska podrška i kodiranje doći u prednji plan u izgradnji budućnosti i jakih ekonomskih struktura, uvođenje kodiranja u predmetne programe postaje tema koju današnji obrazovni sustavi i tvorci politika trebaju razmotriti. Rasprava o kodiranju u kurikulima inovativnih školskih sustava svaki je dan sve sve prisutna. U tom kontekstu, razvijanje vizualno-prostorne inteligencije učenika primjenom kodiranja otvara perspektive učenika spremih za budućnost, ljudi izvan okvira školskoga sustava koji samo poučava kako kodirati.

\section{Zaključci i preporuke}

Najlakši način stjecanja vještina je kroz obrazovanje. Razvijeni obrazovni sustavi orijentirani su na modele učenja zasnovane na činjenju/iskustvu, fokusirani na učenika u cilju obogaćivanja iskustava učenja pojedinaca. Napredak i razvoj ovise o obrazovnim sustavima koji kao prioritete postavljaju iskustva učenja uz upotrebu računalne i informacijske tehnologije s naglaskom na vještine 21 . stoljeća. Zajednička značajka naprednih obrazovnih sustava je njihov naglasak na visokokvalitetne strukture, inovaciju i poduzetništvo. $U$ ovom je istraživanju uvedena algoritamska programska podrška i kodiranje, prihvaćeno od strane uvaženih budućih profesija. Dokazana je viša razina stjecanja znanja i trajnosti nastave učenika koji su iskusili nastavu tehnologije i dizajna kroz činjenje i doživljavanje, integriranu s kodiranjem. Utvrđeno je da poučavanje kodiranjem razvija kognitivne vještine visoke razine, podržava prostorne vještine učenika i omogućuje prijenos znanja na druge predmete jer su učenici imali priliku stvarati nove projekte, što je rezultiralo povećanjem motivacije za predmet. Navedeno smatramo polazišnom točkom za preporuku poučavanja kodiranjem u 
nastavi tehnologije i dizajna, poticanje kodiranja putem prijenosa iskustava u druge predmete, razvijanje testova prostornoga mišljenja za šeste i osme razrede radi dobivanja potrebnih podataka. Dodatno, preporučujemo da se ovo istraživanje koristi kao izvor pri razvoju kurikula predmeta Tehnologije i dizajna te za obrazovanje u području kodiranja u Turskoj Republici Sjeverni Cipar.

Ovo istraživanje nudi program poučavanja koji je utemeljen na analizi i koji će biti potrebna referenca kako bi se prevladao tradicionalni način poučavanja Tehnologije i dizajna u Sjevernom Cipru. Nastava tehnologije i dizajna treba se restrukturirati s drugim predmetima kako bi odgovorila na zahtjeve domaćega tržišta i razvila vještine 21. stoljeća. Uključivanje kodiranja u osmišljavanju nastave Tehnologije i dizajna krucijalno je u održavanju predmeta. Potrebno je osmisliti program koji odgovara interesima i očekivanjima Z generacije. Preporučujemo da se predmeti Tehnologije i dizajna te Informatike kombiniraju u jedan. Nastava Tehnologije i dizajna i poučavanje kodiranja može započeti u primarnom obrazovanju. Naš je savjet da se konzultira ovo istraživanje pri dizajniranju programa nastave Tehnologije i dizajna i Informatike. Kako bi se potvrdio učinak kodiranja na samoučinkovitost, treba provesti istraživanja na naprednim razinama. Moguće je osmisliti različite programe koji bi koristili različite programe kodiranja, a koji bi potvrdili rezultate ovoga istraživanje koje je koristilo program Scratch.

Kako bi se nastava Tehnologije i dizajna učinila funkcionalnijom, očekuje se da se predmet integrira s Informatikom ili se ta dva predmeta mogu spojiti i evaluirati $u$ različitim kontekstima, poput STEM-a. Ovo istraživanje također motivira učitelje da koriste nove tehnologije u svojim predmetima i obrazuju se u području kodiranja. Očekuje se da ova studija pomogne administratorima koji određuju obrazovne strategije i scenarije u kojima će digitalne sposobnosti biti u prvom planu. Također smatramo kako bi ovo istraživanje moglo imati određene implikacije za tvorce obrazovne politike koji će učiniti ovaj predmet funkcionalnijim i integrirati ga s informatičkim vještinama. 